NBER WORKING PAPER SERIES

PERCEPTIONS AND MISPERCEPTIONS OF FISCAL INFLATION

\author{
Eric M. Leeper \\ Todd B. Walker \\ Working Paper 17903 \\ http://www.nber.org/papers/w17903
}

\author{
NATIONAL BUREAU OF ECONOMIC RESEARCH \\ 1050 Massachusetts Avenue \\ Cambridge, MA 02138 \\ March 2012
}

Walker acknowledges support from NSF grant SES-0962221. We would like to thank seminar participants at the NBER Summer Institute, and Alberto Alesina, Michael Bordo, George von Furstenberg, Jordi Gali, Francesco Giavazzi, Juergen von Hagen, Chris Sims and Harald Uhlig for helpful comments. The views expressed herein are those of the authors and do not necessarily reflect the views of the National Bureau of Economic Research.

NBER working papers are circulated for discussion and comment purposes. They have not been peerreviewed or been subject to the review by the NBER Board of Directors that accompanies official NBER publications.

(C) 2012 by Eric M. Leeper and Todd B. Walker. All rights reserved. Short sections of text, not to exceed two paragraphs, may be quoted without explicit permission provided that full credit, including $₫$ notice, is given to the source. 
Perceptions and Misperceptions of Fiscal Inflation

Eric M. Leeper and Todd B. Walker

NBER Working Paper No. 17903

March 2012

JEL No. E31,E52,E62,E63

\begin{abstract}
$\underline{\text { ABSTRACT }}$
The Great Recession and worldwide financial crisis have exploded fiscal imbalances and brought fiscal policy and inflation to the forefront of policy concerns. Those concerns will only grow as aging populations increase demands on government expenditures in coming decades. It is widely perceived that fiscal policy is inflationary if and only if it leads the central bank to print new currency to monetize deficits. Monetization can be inflationary. But it is a misperception that this is the only channel for fiscal inflations. Nominal bonds, the predominant form of government debt in advanced economies, derive their value from expected future nominal primary surpluses and money creation; changes in the price level can align the market value of debt to its expected real backing. This introduces a fresh channel, not requiring explicit monetization, through which fiscal deficits directly affect inflation. The paper describes various ways in which fiscal policy can directly affect inflation and explains why these fiscal effects are difficult to detect in time series data.
\end{abstract}

Eric M. Leeper

Department of Economics

304 Wylie Hall

Indiana University

Bloomington, IN 47405

and Monash University, Australia

and also NBER

eleeper@indiana.edu

Todd B. Walker

Department of Economics

105 Wylie Hall

Indiana University

Bloomington, IN 47405

walkertb@indiana.edu 


\title{
Perceptions and Misperceptions of Fiscal Inflation*
}

\author{
Eric M. Leeper ${ }^{\dagger}$ Todd B. Walker ${ }^{\ddagger}$
}

\section{INTRODUCTION}

Not so long ago, macroeconomists interested in understanding inflation and its determinants were comfortable sweeping fiscal policy under the carpet, implicitly assuming that the fiscal adjustments required to allow monetary policy to control inflation would always be forthcoming. This sanguine view is reflected in recent graduate textbooks, which make scant mention of fiscal policy, and in the economic models at central banks, which all but ignore fiscal phenomena. It is also reflected in the widespread adoption of inflation targeting by central banks, but the nearly complete absence of the adoption of compatible fiscal frameworks.

The Great Recession and accompanying worldwide financial crisis have brought an abrupt halt to researchers' benign neglect of fiscal policy. Figure 1 underlies the sudden shift in attitude among economists and policy makers alike. Fiscal deficits worldwide, but particularly in advanced economies, shot up and public debt as a share of GDP ballooned to nearly 100 percent in advanced economies. As central banks lowered nominal interest rates toward their zero bound, they moved to quantitative actions that dramatically expanded the size and riskiness of their balance sheets. Europe's monetary union has been stressed, perhaps to the breaking point, by member nations' fiscal woes. With both fiscal and monetary authorities taking fiscal actions, professional and policy focuses have now shifted to fiscal matters and the interactions of monetary and fiscal policies.

With the shift in focus has come enhanced interest in the potential channels through which fiscal policy can affect aggregate demand and inflation. And, in light of the facts in figure 1, a pressing question is, "Do profligate fiscal policies threaten the progress many countries have made toward achieving low and stable inflation?" In the conventional monetary paradigm that underlies central bank models and, we conjecture, the thinking of central

\footnotetext{
${ }^{*}$ March 1, 2012. Walker acknowledges support from NSF grant SES-0962221. We would like to thank seminar participants at the NBER Summer Institute, and Alberto Alesina, Michael Bordo, George von Furstenberg, Jordi Galí, Francesco Giavazzi, Jürgen von Hagen, Chris Sims and Harald Uhlig for helpful comments.

†Indiana University, Monash University and NBER; eleeper@indiana.edu.

${ }_{\ddagger}^{\ddagger}$ Indiana University; walkertb@indiana.edu.
} 

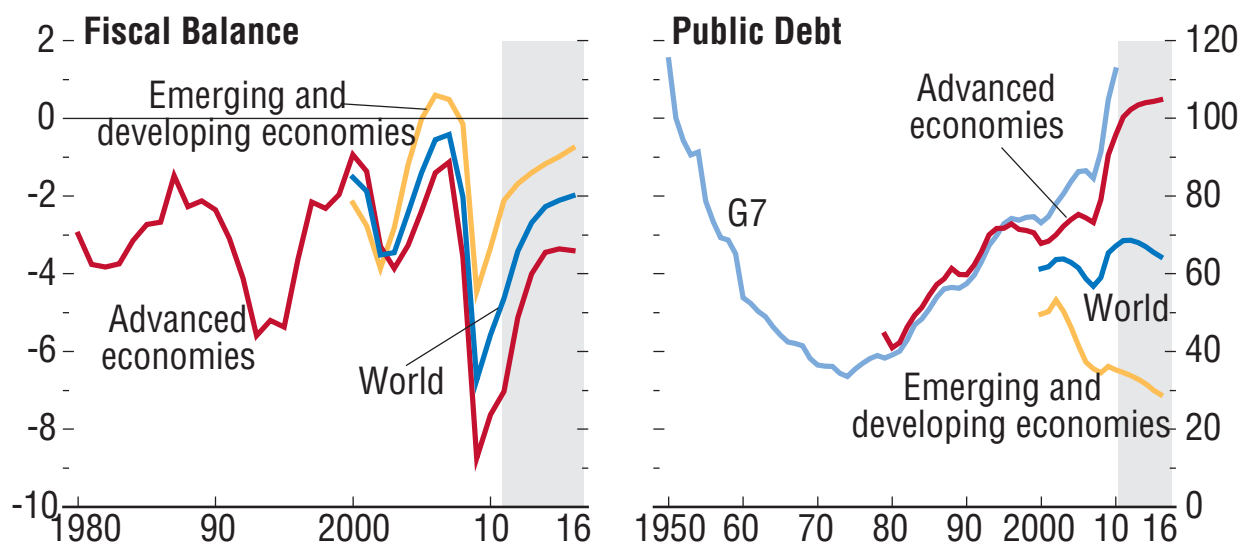

Figure 1: In percent of GDP. Source: International Monetary Fund (2011)

bankers, the answer is, "No, so long as the central bank steadfastly refuses to print new currency to finance deficits."

This paradigm maintains that there is no mechanism by which fiscal policy can be inflationary that is independent of monetary policy and money creation. Sargent and Wallace (1981) model this conventional view and dub it "unpleasant monetarist arithmetic." In their setup, fiscal policy runs a chronic primary deficit - spending exclusive of debt service less tax revenues - that is independent of inflation and government debt and a simple quantity theory demand for money holds, so the price level adjusts to establish money market equilibrium. The economy faces a fiscal limit because the private sector's demand for bonds imposes an upper bound on the debt-GDP ratio. Sargent and Wallace's government bonds are real: claims to payoffs denominated in units of goods.

If primary deficits are exogenous - one notion of "profligate" fiscal policy - and the exogeneity is immutable, then monetary policy loses its ability to control inflation. Standard reasoning underlies the result. If monetary policy initially aims to control inflation by setting money growth independently of fiscal policy, then eventually the exogenous deficit will drive debt to the fiscal limit. At the limit, if government is to remain solvent, monetary policy has no alternative but to print money to generate the seigniorage revenues needed to meet interest payments in the debt. ${ }^{1}$ Eventually, money growth must rise and, by the quantity theory, so must inflation. Long-run monetary policy is driven by the need to stabilize debt and the inflation rate is determined by the size of the total fiscal deficit, including interest

\footnotetext{
${ }^{1}$ We are assuming that in the long run the economy's growth rate is below the real interest rate on debt.
} 
payments.

This conventional paradigm reflects common perceptions of fiscal inflations. But it is a misperception to believe that fiscal policy can affect inflation only if monetary policy monetizes deficits in the manner that Sargent and Wallace envision.

The tight connection between seigniorage financing and inflation in Sargent and Wallace's model stems from the assumption that bonds are real, or perfectly indexed to the price level. Higher real debt requires the government to raise more real resources - like seigniorage - to fully back the debt. But in practice only a small fraction of government debt issued by advanced economies is indexed. Even in the United Kingdom, which has a thick market for indexed government bonds, about 80 percent of outstanding debt is nominal. Ninety percent of U.S. treasuries are nominal and fractions are still higher elsewhere.

Recognizing that bonds are denominated in nominal terms introduces a direct channel from fiscal policy to inflation. Called the fiscal theory of the price level, this channel does not rely on "monetizing deficits" or on insufficient inflation-fighting resolve by the central bank. ${ }^{2}$ Instead, it springs from the fact that a nominal bond is a claim to a nominal payoff-dollars, euros, or shekels - and that the real value of the payoff depends on the price level.

Higher nominal debt may be fully backed by real resources - real primary surpluses and seigniorage - or it may be backed only by nominal cash flows. When real resources fully back the debt, the conventional paradigm prevails and fiscal policy is inflationary only if the central bank monetizes deficits. But when the government cannot or will not raise the necessary real backing, the fiscal theory creates a direct link between current and expected deficits and inflation. ${ }^{3}$

Even though the data in figure 1 have sent some policy makers and financial markets into apoplexy, they are but the tip of the fiscal stress iceberg. Table 1 describes the real problem. Aging populations and promised government old-age benefits that far outstrip revenue provisions imply massive "unfunded liabilities." Plans to bring current deficits under control do little to address the coming fiscal stress. We have no special insights into the political solutions to this unprecedented fiscal problem, but we can shed light on the economic consequences - particularly for inflation - of alternative private-sector beliefs about how the fiscal stress will be resolved.

We work from the premise that central bankers have learned the unpleasant monetarist

\footnotetext{
${ }^{2}$ Leeper (1991), Sims (1994), Woodford (1995), and Cochrane (1998) describe the fiscal theory and its implications.

${ }^{3}$ The terms "fiscal theory" and "quantity theory" are unfortunate because they suggest that these are distinct models of price-level determination. As we show, the price level and inflation always depend on both monetary and fiscal policy behavior. The fiscal and quantity "theories" emerge under alternative monetary-fiscal regimes, as Gordon and Leeper (2006) show.
} 


\begin{tabular}{lr}
\hline Country & $\begin{array}{r}\text { Aging-Related } \\
\text { Spending }\end{array}$ \\
\hline \hline Australia & 482 \\
Canada & 726 \\
France & 276 \\
Germany & 280 \\
Italy & 169 \\
Japan & 158 \\
Korea & 683 \\
Spain & 652 \\
United Kingdom & 335 \\
United States & 495 \\
Advanced G-20 Countries & 409 \\
\hline
\end{tabular}

Table 1: Net present value of impact on fiscal deficit of aging-related spending, in percent of GDP. Source: International Monetary Fund (2009).

arithmetic lesson, so explicit monetization of deficits is off the table in advanced economies. though this is not a universally held view [Cochrane (2011b)]. For the most part, we also exclude outright default on the government liabilities of those countries. On-going developments in the euro area vividly illustrate the lengths to which policy makers will go to avoid default, and policy makers in the United Kingdom, the United States, and elsewhere hold similar views.

There remain two possible resolutions to fiscal stress. First, government could successfully persuade the public that future revenue and spending adjustments will occur. With fiscal policy taking care of itself, we return to the sanguine world in which central banks retain control of inflation. Numbers in table 1 underscore how large those adjustments must be. Economic theory tells us that those policies must also be credible to firmly anchor expectations on the necessary fiscal adjustments, which is what is required for monetary policy to retain control of inflation as in the conventional paradigm.

Because the first resolution is well understood, the paper focuses on a variety of alternative policy scenarios in which aspects of the second resolution-price-level changes induced by the fiscal theory - come into play. We focus on the fiscal theory because it seems to be poorly understood and quickly discarded by central bankers. For example, in their discussion of the implications of fiscal stress for central banks, Cecchetti, Mohanty, and Zampolli (2010, footnote 23) acknowledge the fiscal theory, but immediately dismiss it as "untested and controversial." As we point out below, the fiscal theory is no more or less "testable" than the quantity theory or its recent offspring, the new Keynesian/Taylor rule model of inflation. And it is "controversial," we believe, because it is relatively new, its implications 
are unsettling, and its economic mechanisms have not yet been fully absorbed by monetary economists and policy makers.

1.1 What We Do Section 2 uses a simple model to illustrate how the price level is determined in the conventional paradigm and in the fiscal theory. The conventional policy mix - Regime M-has monetary policy target inflation and fiscal policy stabilize the value of debt. An alternative mix - Regime F-is available when governments issue nominal bonds. That mix assigns monetary policy to stabilize debt and fiscal policy to control the price level, giving rise to the fiscal theory equilibrium.

In Regime M, deficit-financed tax cuts or spending increases do not affect aggregate demand because the private sector expects the resulting increase in government debt to be exactly matched by future tax increases or spending reductions. Expansions in government debt do not raise wealth. This fiscal behavior relieves monetary policy of debt stabilization, freeing the central bank to target inflation.

Regime $\mathrm{F}$ posits different policies that align closely to actual behavior in many countries recently. Suppose that higher deficits do not create higher expected surpluses and that central banks either peg short-term nominal interest rates or raise them only weakly with inflation. Because a tax cut today does not portend future tax hikes, individuals initially perceive the increase in nominal debt to be an increase in their real wealth. They try to convert higher wealth into consumption goods, raising aggregate demand. Rising demand brings with it rising prices, which continue to rise until real wealth falls back to its pre-taxcut level and individuals are content with their original consumption plans. By preventing nominal interest rates from rising sharply with inflation, monetary policy prevents debt service from growing too rapidly, which stabilizes the value of government bonds. In this stylized version of the fiscal theory, monetary policy can anchor expected inflation on the inflation target, but fiscal policy determines actual inflation.

The section goes on to describe how the maturity structure of nominal government bonds can alter the time series properties of inflation and it lays out the precise role that monetary policy plays in a fiscal equilibrium. A fiscal theory equilibrium is consistent with a wide range of patterns of correlation in data, including a positive correlation between inflation and money growth, a negative correlation between inflation and the debt-GDP ratio, and any correlation between inflation and nominal debt growth and deficits.

Having established that under Regime F policies monetary policy does not control inflation, section 3 turns to plausible scenarios in which the central bank does not control inflation even in Regime M. One example arises when the public believes the economy may hit its fiscal limit, the point at which taxes and spending can no longer adjust to stabilize debt, at 
some point in the future. Even if monetary policy aggressively targets inflation in the years before the limit, it cannot determine the inflation rate and it cannot even anchor expected inflation. A second type of fiscal limit stems from the risk of sovereign default. When the central bank sets the interest rate on short-term government bonds, a higher probability of default feeds directly into current inflation. Finally, in a monetary union, the member nation whose fiscal policies are profligate will determine the union-wide price level, even if other member countries run fiscal policies that consistently target real debt.

In section 4 the paper turns to consider the empirical implications of monetary-fiscal policy interactions. That section lays out some observational equivalence results that arise in models of section 2. Restrictions on policy behavior and/or exogenous driving processes are crucial in discerning whether observed time series on inflation, debt, and deficits are generated by a Regime M or a Regime F equilibrium.

Central bankers who aim to hit an inflation target, need to know whether the economy resides in Regime $\mathrm{M}$ or in Regime $\mathrm{F}$. Observational equivalence informs us that existing research may not be able to address this fundamental issue without first confronting the observational equivalence problem. Until we tackle this formidable empirical challenge, we cannot use data to distinguish perceptions from misperceptions about fiscal inflation.

The paper leaves many important topics unexplored. For analytical clarity, we consider only endowment economies with flexible prices. Kim (2003), Woodford (1998b), Cochrane (2011a), and Sims (2011) study the fiscal theory in sticky-price models. We also do not explore the differences among debt devaluations arising from price-level changes, outright default, and debt dilution - all issues that are particularly timely now. Untouched by our paper are the game-theoretic aspects of monetary-fiscal interactions that Dixit and Lambertini (2001, 2003a,b) and Bassetto (2002) study.

\section{Simple Model of Monetary-Fiscal Interactions}

We present a simple analytical model of price-level and inflation determination that is designed to illustrate the role that the interactions between monetary and fiscal policies play in the inflation process. Throughout the analysis we restrict attention to rational expectations equilibria, so the results can be readily contrasted to prevailing views, which also are based on rational expectations.

The model draws from Leeper (1991), Sims (1994), and Woodford (2001) to lay the groundwork for how monetary and fiscal policies jointly determine equilibrium. These results are well known, but the broader implications of thinking about macro policies jointly are not fully appreciated.

An infinitely lived representative household is endowed each period with a constant quan- 
tity of non-storable goods, $y$. To keep the focus away from seigniorage considerations, we initially examine a cashless economy, which can be obtained by making the role of fiat currency infinitesimally small. (The next section brings money back into the picture.) Government issues nominal one-period bonds, allowing us to define the price level, $P$, as the rate at which bonds exchange for goods.

The household chooses sequences of consumption and bonds, $\left\{c_{t}, B_{t}\right\}$, to maximize

$$
E_{0} \sum_{t=0}^{\infty} \beta^{t} u\left(c_{t}\right), \quad 0<\beta<1
$$

subject to the budget constraint

$$
c_{t}+\frac{B_{t}}{P_{t}}+\tau_{t}=y+z_{t}+\frac{R_{t-1} B_{t-1}}{P_{t}}
$$

taking prices and $R_{-1} B_{-1}>0$ as given. The household pays taxes, $\tau_{t}$, and receives transfers, $z_{t}$, each period, both of which are lump sum.

Government spending is zero each period, so the government chooses sequences of taxes, transfers, and debt to satisfy its flow constraint

$$
\frac{B_{t}}{P_{t}}+\tau_{t}=z_{t}+\frac{R_{t-1} B_{t-1}}{P_{t}}
$$

given $R_{-1} B_{-1}>0$, while the monetary authority chooses a sequence for the nominal interest rate.

After imposing goods market clearing, $c_{t}=y$ for $t \geq 0$, the household's consumption Euler equation reduces to the simple Fisher relation

$$
\frac{1}{R_{t}}=\beta E_{t}\left(\frac{P_{t}}{P_{t+1}}\right)
$$

The exogenous (fixed) gross real interest rate, $1 / \beta$, makes the analysis easier but is not without some lose of generality, as Davig, Leeper, and Walker (2010) show in the context of fiscal financing in a model with nominal rigidities. This is less the case in a small open economy, so one interpretation of this model is that it is a small open economy in which government debt is denominated in terms of the home nominal bonds ("currency") and all debt is held by domestic agents.

The focus on price-level determination is entirely for analytical convenience; it is not a statement that inflation is the only thing that macro policy authorities do or should care about. Because price-level determination is the first step toward understanding how macro 
policies affect the aggregate economy, the key insights derived from this model extend to more complex environments.

Price-level determination depends on monetary-fiscal policy behavior. At a general level, macroeconomic policies have two tasks to perform: control inflation and stabilize government debt. Monetary and fiscal policy are perfectly symmetric with regard to the two tasks and two different policy mixes can accomplish the tasks. The conventional assignment of tasksRegime M-instructs monetary policy to target inflation and fiscal policy to target real debt (or the debt-GDP ratio). But an alternative assignment-Regime F-also works: monetary policy is tasked with maintaining the value of debt and fiscal policy is assigned to control inflation. We now describe these two regimes in detail.

2.1 Regime M: Active Monetary/Passive Tax Policy This policy regime reproduces wellknown results about how inflation is determined in the canonical model of monetary policy, as presented in textbooks by Woodford (2003) and Galí (2008), for example. This regimedenoted active monetary and passive fiscal policy - combines an interest rate rule in which the central bank aggressively adjusts the nominal rate in response to current inflation with a tax rule in which the tax authority adjusts taxes in response to government debt sufficiently to stabilize debt. ${ }^{4}$ In this textbook world, monetary policy can consistently hit its inflation target and fiscal policy can achieve its target for the real value of debt.

To derive the equilibrium price level for the model laid out above, we need to specify rules for monetary, tax, and transfers policies. Monetary policy follows a conventional interest rate rule, which for analytical convenience, is written somewhat unconventionally in terms of the inverse of the nominal interest and inflation rates

$$
R_{t}^{-1}=R^{*-1}+\alpha\left(\frac{P_{t-1}}{P_{t}}-\frac{1}{\pi^{*}}\right), \quad \alpha>1 / \beta
$$

where $\pi^{*}$ is the inflation target and $R^{*}=\pi^{*} / \beta$ is the steady state nominal interest rate. The condition on the policy parameter $\alpha$ ensures that monetary policy is sufficiently hawkish in response to fluctuations in inflation that it can stabilize inflation around $\pi^{*}$.

Fiscal policy adjusts taxes in response to the state of government debt

$$
\tau_{t}=\tau^{*}+\gamma\left(\frac{B_{t-1}}{P_{t-1}}-b^{*}\right), \quad \gamma>r=1 / \beta-1
$$

\footnotetext{
${ }^{4}$ Applying Leeper's (1991) definitions, "active" monetary policy targets inflation, while "passive" monetary policy weakly adjusts the nominal interest rate in response to inflation; "active" tax policy sets taxes independently of government debt and "passive" tax policy changes rates strongly enough when debt rises to stabilize the debt-GDP ratio. Or fiscal policy could be associated with setting transfers instead of taxes.
} 
where $b^{*}$ is the real debt (or debt-GDP) target, $\tau^{*}$ is the steady state level of taxes, and $r=1 / \beta-1$ is the net real interest rate. Imposing that $\gamma$ exceeds the net real interest rate guarantees that any increase in government debt creates an expectation that future taxes will rise by enough to both service the higher debt and retire it back to $b^{*}$.

Government transfers evolve exogenously according to the stochastic process

$$
z_{t}=(1-\rho) z^{*}+\rho z_{t-1}+\varepsilon_{t}, \quad 0<\rho<1
$$

where $z^{*}$ is steady-state transfers and $\varepsilon_{t}$ is a serially uncorrelated shock with $E_{t} \varepsilon_{t+1}=0$.

Equilibrium inflation is obtained by combining (4) and (5) to yield the difference equation

$$
\frac{\beta}{\alpha} E_{t}\left(\frac{P_{t}}{P_{t+1}}-\frac{1}{\pi^{*}}\right)=\frac{P_{t-1}}{P_{t}}-\frac{1}{\pi^{*}}
$$

Aggressive reactions of monetary policy to inflation imply that $\beta / \alpha<1$ and the unique bounded solution for inflation is

$$
\pi_{t}=\pi^{*}
$$

so equilibrium inflation is always on target, as is expected inflation. ${ }^{5,6}$

If monetary policy determines inflation, how must fiscal policy respond to disturbances in transfers to ensure that policy is sustainable? This is where passive tax adjustments step in. Substituting the tax rule, (6), into the government's budget constraint, (3), taking expectations conditional on information at $t-1$, and employing the Fisher relation, (4), yields the expected evolution of real debt

$$
E_{t-1}\left(\frac{B_{t}}{P_{t}}-b^{*}\right)=E_{t-1}\left(z_{t}-z^{*}\right)+\left(\beta^{-1}-\gamma\right)\left(\frac{B_{t-1}}{P_{t-1}}-b^{*}\right)
$$

Because $\beta^{-1}-\gamma<1$, debt that is above target brings forth the expectation of higher taxes, so (10) describes how debt is expected to return to steady state following a shock to $z_{t}$. In

\footnotetext{
${ }^{5}$ As Sims (1999) and Cochrane (2011a) emphasize, echoing Obstfeld and Rogoff (1983), there is a continuum of explosive solutions to (8), each one associated with the central bank threatening to drive inflation to infinity if the private sector's expectations are not anchored on $\pi^{*}$. Cochrane uses this logic to argue that fundamentally only fiscal policy can uniquely determine inflation and the price level. Sims argues, in a monetary model that supports a barter equilibrium, that only a fiscal commitment to a floor value of real money balances can deliver a unique equilibrium. Determinacy comes from the fiscal authority committing to switch from a passive stance if the price level gets too high to adopt a policy that redeems government liabilities at a fixed floor real value. If the fiscal commitment is believed, in equilibrium, this fiscal "backstop" will never need to be used and only stable price-level paths will be realized. Both Cochrane and Sims argue that there is nothing monetary policy alone can do to eliminate the explosive price-level paths.

${ }^{6}$ Although there is a unique bounded inflation process, this regime does not pin down the price-level process.
} 
a steady state in which $\varepsilon_{t} \equiv 0$, debt is $b^{*}=\left(\tau^{*}-z^{*}\right) /\left(\beta^{-1}-1\right)$, equal to the present value of primary surpluses.

Another perspective on the fiscal financing requirements when monetary policy is targeting inflation emerges from a ubiquitous equilibrium condition. In any dynamic model with rational agents, government debt derives its value from its anticipated backing. In this model, that anticipated backing comes from tax revenues net of transfer payments, $\tau_{t}-z_{t}$. The value of government debt can be obtained by imposing equilibrium on the government's flow constraint, taking conditional expectations, and "solving forward" to arrive at

$$
\frac{B_{t}}{P_{t}}=E_{t} \sum_{j=1}^{\infty} \beta^{j}\left(\tau_{t+j}-z_{t+j}\right)
$$

This intertemporal equilibrium condition provides a new perspective on passive tax policy. Because $P_{t}$ is nailed down by monetary policy and $\left\{z_{t+j}\right\}_{j=1}^{\infty}$ is being set independently of both monetary and tax policies, any increase in transfers at $t$, which is financed by new sales of nominal $B_{t}$, must generate an expectation that taxes will rise in the future by exactly enough to support the higher value of real $B_{t} / P_{t}$.

In this model, the only potential source of an expansion in debt is disturbances to transfers. But passive tax policy implies that this pattern of fiscal adjustment must occur regardless of the reason that $B_{t}$ increases: economic downturns that automatically reduce taxes and raise transfers, changes in household portfolio behavior, changes in government spending, or central bank open-market operations. To expand on the last example, we could modify this model to include money to allow us to imagine that the central bank decides to tighten monetary policy exogenously at $t$ by conducting an open-market sale of bonds. If monetary policy is active, then the monetary contraction both raises $B_{t}$-bonds held by households - and it lowers $P_{t}$; real debt rises from both effects. This can be an equilibrium only if fiscal policy is expected to support it by passively raising future real tax revenues. That is, given active monetary policy, (11) imposes restrictions on the class of tax policies that is consistent with equilibrium; those policies are labeled "passive" because the tax authority has limited discretion in choosing policy. Refusal by tax policy to adjust appropriately undermines the ability of open-market operations to affect inflation in the conventional manner, just as Wallace (1981) illustrates.

A policy regime in which monetary policy is active and tax policy is passive produces the conventional outcome that inflation is always and everywhere a monetary phenomenon and a hawkish central bank can successfully anchor actual and expected inflation at the inflation target. Tax policy must support the active monetary behavior by passively adjusting taxes to finance disturbances to government debt-from whatever source, including monetary 
policy — and ensure policy is sustainable.

Although conventional, this regime is not the only mechanism by which monetary and fiscal policy can jointly deliver a unique bounded equilibrium. We turn now to the other polar case.

2.2 Regime F: Passive Monetary/Active Tax Policy Passive tax behavior is a stringent requirement: the tax authority must be willing and able to raise taxes in the face of rising government debt. For a variety of reasons, this does not always happen, and it certainly does not happen in the automated way prescribed by the tax rule in (6). Political factors may prevent taxes from rising as needed to stabilize debt, as in the United States today. ${ }^{7}$ Some countries simply do not have the fiscal infrastructure in place to generate the necessary tax revenues. Others might be at or near the peak of their Laffer curves, suggesting they are close to the fiscal limit. ${ }^{8}$ In this case, tax policy is active and $0 \leq \gamma<1 / \beta-1$.

Analogously, there are also periods when the concerns of monetary policy move away from inflation stabilization and toward other matters, such as output stabilization or financial crises. These are periods in which monetary policy is no longer active, instead adjusting the nominal interest rate only weakly in response to inflation. Woodford (2001) cites the Federal Reserve's bond-price pegging policy during and immediately after World War II as an example of passive monetary policy. Bordo and Hautcoeur (2007) point out that the Banque de France pegged nominal bond prices in the 1920s at the same time that political gridlock prevented the fiscal adjustments necessary to stabilize debt. Inflation rose and the franc depreciated during this mix of passive monetary and active fiscal policies. The recent global recession and financial crisis is a striking case where central banks' concerns shifted away from inflation. In some countries the policy rate was reduced to its zero lower bound. Then monetary policy is passive and, in terms of policy rule (5), $0 \leq \alpha<1 / \beta$.

We focus on a particular policy mix that yields clean economic interpretations: the nominal interest rate is set independently of inflation, $\alpha=0$ and $R_{t}^{-1}=R^{*-1} \geq 1$, and taxes are set independently of debt, $\gamma=0$ and $\tau_{t}=\tau^{*}>0$. These policy specifications might seem extreme and special, but the qualitative points that emerge generalize to other specifications of passive monetary/active tax policies.

One result pops out immediately. Applying the pegged nominal interest rate policy to

\footnotetext{
${ }^{7}$ Davig and Leeper $(2006,2011)$ generalize (6) to estimate Markov switching rules for the United States and find that tax policy has switched between periods when taxes rise with debt and periods when they do not.

${ }^{8}$ Trabandt and Uhlig (2010) characterize Laffer curves for capital and labor taxes in 14 EU countries and the United States to find that some countries - Denmark and Sweden - are on the wrong side of the curve, suggesting that those countries must lower tax rates to raise revenues.
} 
the Fisher relation, (4) yields

$$
E_{t}\left(\frac{P_{t}}{P_{t+1}}\right)=\frac{1}{\beta R^{*}}=\frac{1}{\pi^{*}}
$$

so expected inflation is anchored on the inflation target, an outcome that is perfectly consistent with one aim of inflation-targeting central banks. It turns out, however, that another aim of inflation targeters - stabilization of actual inflation - which can be achieved by active monetary/passive fiscal policy, is no longer attainable.

Impose the active tax rule on the intertemporal equilibrium condition, (11)

$$
\frac{B_{t}}{P_{t}}=\left(\frac{\beta}{1-\beta}\right) \tau^{*}-E_{t} \sum_{j=1}^{\infty} \beta^{j} z_{t+j}
$$

and use the government's flow constraint, (3), to solve for the price level

$$
P_{t}=\frac{R^{*} B_{t-1}}{\left(\frac{1}{1-\beta}\right) \tau^{*}-E_{t} \sum_{j=0}^{\infty} \beta^{j} z_{t+j}}
$$

At time $t$, the numerator of this expression is predetermined, representing the nominal value of household wealth carried into period $t$. The denominator is the expected present value of primary fiscal surpluses from date $t$ on, which is exogenous. So long as $R^{*} B_{t-1}>0$ and the present value of revenues exceeds the present value of transfers, a condition that must hold if government debt has positive value, expression (14) delivers a unique $P_{t}>0$. In contrast to the active monetary/passive fiscal regime, this policy mix uniquely determines both inflation and the price level.

We have done nothing mystical here, despite what some critics claim [for example, Buiter (2002) or McCallum (2001)]. In particular, the government is not assumed to behave in a manner that violates its budget constraint. Unlike competitive households, the government is not required to choose sequences of control variables that are consist with its budget constraint for all possible price sequences. Indeed, for a central bank to target inflation, it cannot be choosing its policy instrument to be consistent with any sequence of the price level; doing so would produce an indeterminate equilibrium. Identical reasoning applies to the fiscal authority: the value of a dollar of debt- $1 / P_{t}$ - depends on expectations about fiscal decisions in the future; expectations, in turn, are determined by the tax rule the fiscal authority announces. The fiscal authority credibly commits to its tax rule and, given the process for transfers, this determines the backing of government debt and, therefore, its market value. 
Using the solution for the price level in (14) to compute expected inflation, it is straightforward to show that $\beta E_{t}\left(P_{t} / P_{t+1}\right)=1 / R^{*}$, as required by the Fisher relation and monetary policy behavior. ${ }^{9}$ This observation leads to a sharp dichotomy between the roles of monetary and fiscal policy in price-level determination: monetary policy alone appears to determine expected inflation by choosing the level at which to peg the nominal interest rate, $R^{*}$, while conditional on that choice, fiscal variables appear to determine realized inflation. Monetary policy's ability to target expected inflation holds in this simple model with a fixed policy regime; as we show in section 3 , when regime change is possible, monetary policy may not be able to control even expected inflation.

To understand the nature of this equilibrium, we need to delve into the underlying economic behavior. This is an environment in which changes in debt do not elicit any changes in expected taxes, unlike in section 2.1. First consider a one-off increase in current transfer payments, $z_{t}$, financed by new nominal debt issuance, $B_{t}$. With no offsetting increase in current or expected tax obligations, at initial prices households feel wealthier and they try to shift up their consumption paths. Higher demand for goods drives up the price level and continues to do so until the wealth effect dissipates and households are content with their initial consumption plan. This is why in expression (13) the value of debt at $t$ changes with expected, but not current, transfers. Now imagine that at time $t$ households receive news of higher transfers in the future. In the first instance, there is no change in nominal debt at $t$, but there is still an increase in household wealth. Through the same mechanism, $P_{t}$ must rise to revalue current debt to be consistent with the new expected path of transfers: the value of debt falls in line with the lower expected present value of surpluses.

Cochrane (2009, p. 5) offers another interpretation of the equilibrium in which "aggregate demand' is really just the mirror image of demand for government debt." An expectation that transfers will rise in the future reduces the household's assessment of the value of government debt. Households can shed debt only by converting it into demand for consumption goods, hence the increase in aggregate demand that translates into a higher price level.

Expression (14) highlights that in this policy regime the impacts of monetary policy change dramatically. When the central bank chooses a higher rate at which to peg the nominal interest rate, the effect is to raise the inflation rate next period. This echoes Sargent and Wallace (1981), but the economic mechanism is different. In the current policy

${ }^{9}$ To see this, compute

$$
E_{t-1} \frac{1}{P_{t}}=\frac{\left(\frac{1}{1-\beta}\right) \tau^{*}-E_{t-1} \sum_{j=0}^{\infty} \beta^{j} z_{t+j}}{R^{*} B_{t-1}}
$$

To find expected inflation, simply use the date $t-1$ version of (14) for $P_{t-1}$ and simplify to obtain $\beta E_{t-1}\left(P_{t-1} / P_{t}\right)=1 / R_{t-1}=1 / R^{*}$. 
mix, a higher nominal interest rate raises the interest payments the household receives on the government bonds it holds. Higher $R^{*} B_{t-1}$, with no higher anticipated taxes raises household nominal wealth at the beginning of $t$, triggering the same adjustments as above. In this sense, as in Sargent and Wallace, monetary policy has lost control of inflation.

This section has reviewed existing results on price-level determination under alternative monetary-fiscal policy regimes. In each regime a bounded inflation rate is uniquely determined, but the impacts of changes in policy differ markedly across the two regimes. We now turn to elaborate on a key difference between the fiscal theory and unpleasant arithmetic.

2.3 Why the Fiscal Theory is Not Unpleasant Arithmetic It is not uncommon for policy makers to equate fiscal inflations to the mechanism that Sargent and Wallace (1981) highlighted and then to dismiss its relevance. As King (1995, p. 171-172) wrote about unpleasant arithmetic:

"I have never found this proposition very convincing... . [A]s an empirical matter, the proposition is of little current relevance to the major industrial countries. This is for two reasons. First, seigniorage - financing the deficit by issuing currency rather than bonds - is very small relative to other sources of revenues. Second, over the past decade or so, governments have become increasingly committed to price stability... This sea change in the conventional wisdom about price stability leaves no room for inflation to bail out fiscal policy."

Later in the same commentary, King [p. 173] acknowledges that "...periodic episodes of unexpected inflation... have reduced debt-to-GDP ratios." This observation is consistent with the fiscal theory, though King does not attribute the inflation to fiscal news.

A fiscal theory equilibrium can be consistent with any average rate of inflation and money creation. This point emerges clearly in Leeper's (1991) local analysis around a given deterministic steady state: on average inflation could be zero, yet monetary and fiscal shocks generate all the results shown in section 2.2. In the model above, the unconditional mean of inflation is $\pi^{*}$, the inflation target, and in a monetary version of the model, $\pi^{*}$ is determined by average money growth (or seigniorage revenues).

A key difference between the fiscal theory and unpleasant arithmetic is that the former operates only in an economy with nominal government debt, whereas the latter is typically discussed under the assumption of real debt. Without a fully fleshed-out model, the distinction between nominal and real debt can be understood by examining the corresponding intertemporal equilibrium conditions - the analogs to (13). We add fiat currency to make a 
point about the role of seigniorage revenues. For nominal debt the equilibrium condition is

$$
B_{t-1}=P_{t} \sum_{j=0}^{\infty} \beta^{j} E_{t}\left[\tau_{t+j}-z_{t+j}+\frac{M_{t+j}-M_{t+j-1}}{P_{t+j}}\right]
$$

while for real debt, $v_{t}$, it is

$$
v_{t-1}=\sum_{j=0}^{\infty} \beta^{j} E_{t}\left[\tau_{t+j}-z_{t+j}+\frac{M_{t+j}-M_{t+j-1}}{P_{t+j}}\right]
$$

Both conditions involve the expected present value of primary surpluses plus seigniorage. The fiscal theory is about how changes in this expected present value lead to changes in $P_{t}$. Unpleasant arithmetic is about how increases in $v_{t-1}$ induce increases in expected future seigniorage, $\left(M_{t+j}-M_{t+j-1}\right) / P_{t}$.

To understand the differences, consider a hypothetical increase in $P_{t}$, holding all else fixed. In (15), higher $P_{t}$ raises the nominal backing to debt, so it implies higher cash flows in the form of nominal primary surpluses: more nominal debt can be supported with no change in real surpluses or seigniorage. In (16), higher $P_{t}$ lowers the real backing to debt because it reduces seigniorage revenues and real cash flows.

This makes clear why the fiscal theory is not about seigniorage: even if real balances are arbitrarily small or the economy is on the wrong side of the seigniorage Laffer curve, under the fiscal theory, higher $P_{t}$ increases the backing of debt by raising the nominal cash flows associated with primary surpluses. In this case, as (16) shows, higher $P_{t}$ does nothing to affect the backing of real debt.

\subsection{Regime F: Two-Period Government Debt Restricting attention to one-period} debt makes it seem that fiscal news must generate jumps in the current price level. This need not happen. To get a richer sense of inflation dynamics in the passive monetary/active fiscal regime, suppose that the government issues nominal bonds with a maximum maturity of two periods. Let $B_{t}(j)$ denote the face value of zero-coupon nominal bonds outstanding at the end of period $t$, which mature in period $j$ and let $Q_{t}(j)$ be the corresponding nominal price for those bonds. At the beginning of period $t$, the nominal returns, $R_{t}(t+1)$ and $R_{t}(t+2)$, are known with certainty and are risk free. Clearly, $R_{t}(t+1)^{-1}=Q_{t}(t+1)$, $R_{t}(t+2)^{-1}=Q_{t}(t+2), Q_{t}(t)=1$ and $B_{t}(j)=0$ for $j \leq t$. To economize on notation, we assume that each period the government retires outstanding debt and issues new one- and two-period bonds. 
The government's flow budget constraint is

$$
\frac{Q_{t}(t+1) B_{t}(t+1)}{P_{t}}+\frac{Q_{t}(t+2) B_{t}(t+2)}{P_{t}}+x_{t}=\frac{B_{t-1}(t)}{P_{t}}+\frac{Q_{t}(t+1) B_{t-1}(t+1)}{P_{t}}
$$

where $x_{t}$ is the primary surplus inclusive of seigniorage revenues, defined as

$$
x_{t} \equiv \tau_{t}-z_{t}+\frac{M_{t}-M_{t-1}}{P_{t}}
$$

where $M_{t}$ is the nominal quantity of fiat money outstanding.

We bring money in by positing a simple, interest inelastic, demand for money ${ }^{10}$

$$
\frac{M_{t}}{P_{t}}=f\left(c_{t}\right)
$$

that, in equilibrium, implies that real money balances are constant

$$
\frac{M_{t}}{P_{t}}=k
$$

In a frictionless economy with a constant real interest rate, the household's Euler equation deliver the one- and two-period nominal bond prices

$$
\begin{aligned}
& Q_{t}(t+1)=\beta E_{t}\left(\frac{P_{t}}{P_{t+1}}\right) \\
& Q_{t}(t+2)=\beta E_{t} Q_{t+1}(t+2)\left(\frac{P_{t}}{P_{t+1}}\right)
\end{aligned}
$$

Using (21) in (22) yields

$$
Q_{t}(t+2)=\beta^{2} E_{t}\left(\frac{P_{t}}{P_{t+2}}\right)
$$

Take expectations of the government budget constraint, impose the asset-pricing relations and the transversality condition, which requires the expected present value of the market value of debt to be zero, to obtain the intertemporal equilibrium condition

$$
\frac{Q_{t}(t+1) B_{t}(t+1)+Q_{t}(t+2) B_{t}(t+2)}{P_{t}}=\sum_{i=1}^{\infty} \beta^{i} E_{t} x_{t+i}
$$

\footnotetext{
${ }^{10}$ This specification may be obtained from a cash-in-advance model or from money-in-utility/transactionscost models in which the interest elasticity is driven to the zero limit.
} 
Combining (24) with the government's flow constraint, (17), yields

$$
\frac{B_{t-1}(t)+Q_{t}(t+1) B_{t-1}(t+1)}{P_{t}}=\sum_{i=0}^{\infty} \beta^{i} E_{t} x_{t+i}
$$

The left side of (25) is the market value of debt outstanding at the beginning of period $t$. Two terms in this value - the face value of outstanding nominal bonds, $B_{t-1}(t)$ and $B_{t-1}(t+1)-$ are carried into period $t$ from period $t-1$, so they are predetermined at $t$. But two other terms - the price of two-period bonds issued at $t-1$ and sold at $t, Q_{t}(t+1)$, and the price level, $P_{t}$-are determined at period $t$ and respond to shocks and news that arrive at $t$.

Using equilibrium relationship (21) in (25) makes clear the tradeoffs that monetary policy faces when primary surpluses are fixed

$$
\frac{B_{t-1}(t)}{P_{t}}+\beta B_{t-1}(t+1) E_{t} \frac{1}{P_{t+1}}=\sum_{i=0}^{\infty} \beta^{i} E_{t} x_{t+i}
$$

Monetary policy faces two limiting cases. It can lean strongly against current inflation to fix $P_{t}$, but then it must permit future inflation, $E_{t}\left(1 / P_{t+1}\right)$, to adjust. Alternatively, it can stabilize expected inflation at $t+1$, but then it must allow $P_{t}$ to adjust. The tradeoff between current and future inflation depends on the ratio $B_{t-1}(t+1) / B_{t-1}(t)$, the ratio between the outstanding quantities of two-period to one-period bonds, a role for the maturity structure of government debt that Cochrane (2001) emphasizes. As debt becomes of increasingly short maturity, this ratio falls and a larger change in expected inflation is required to compensate for a given change in current inflation.

2.4.1 Fiscal Expansions and Inflation We employ the two equilibrium conditions, (20) and (26), to derive the implications for inflation of alternative policy environments. Monetary policy controls the one-period nominal bond price, $Q_{t}(t+1)$, which is equivalent to controlling the short-term nominal interest rate, $R_{t}=1 / Q_{t}(t+1)$.

For this exposition, we make the simplifying assumption that the primary surplus, $\left\{\tau_{t}-\right.$ $\left.z_{t}\right\}$ is exogenous or at least independent of the price level and the value of outstanding government debt. This may seem like an extreme and implausible assumption in light of Hall and Sargent's (2011) accounting that since World War II, adjustments in primary surpluses have been an important determinant of U.S. debt-GDP dynamics. Of course, Hall and Sargent's is an accounting exercise that does not aim to establish that fluctuations in government debt caused subsequent surplus adjustments that were designed to stabilize debt. ${ }^{11}$ But even if we make the bold assumption of causality, Hall and Sargent do not find

\footnotetext{
${ }^{11}$ ? is often cited as evidence that establishes this causality, but his methods cannot distinguish between
} 
that surpluses always adjust to rationalize the value of debt. Other evidence, whose causal interpretation is also in question, suggests that U.S. fiscal policy has fluctuated between regimes in which policies systematically raise future surpluses in response to high debt and regimes in which surpluses evolve largely independently of debt [Davig and Leeper (2006)].

The fiscal stress that advanced economies face is extreme relative to experiences of those economies since World War II. Given the political economy forces at play, simple extrapolations of past policy behavior into coming decades are tenuous at best. Assuming that fiscal policy will go through periods in which surpluses are set independently of debt or that private decision makers believe such periods are possible - even likely - is a reasonable working assumption. Exogenous surpluses are a tractable way to examine the qualitative nature of equilibria in which debt is not systematically stabilized by primary surpluses.

We take the primary fiscal surplus sequence, $\left\{\tau_{t}-z_{t}\right\}$, as exogenous and imagine that information arrives at $t$ that causes agents to revise downward their views about current or expected surpluses.

The first term on the right side of (26) may be written as $x_{t}=\tau_{t}+s_{t}-z_{t}$. In equilibriumimposing equilibrium condition (20) - seigniorage is

$$
s_{t}=\frac{M_{t}-M_{t-1}}{P_{t}}=k-\frac{M_{t-1}}{P_{t}}
$$

Then the second equilibrium condition, (26), becomes

$$
\frac{B_{t-1}(t)+M_{t-1}}{P_{t}}+\beta B_{t-1}(t+1) E_{t} \frac{1}{P_{t+1}}=k+\tau_{t}-z_{t}+\sum_{i=1}^{\infty} \beta^{i} E_{t} x_{t+i}
$$

For a given debt maturity structure, summarized by the ratio $B_{t}(t+2) / B_{t}(t+1)$, monetary policy behavior determines the mix of current and expected inflation that arises from lower current or anticipated surpluses.

Current Inflation Suppose initially that the central bank pegs the short-bond price at $Q_{t}(t+1)=Q^{*}$ for all $t$, effectively pegging expected inflation through the Euler equation, (21). Then (28) becomes

$$
\frac{W_{t-1}}{P_{t}}=\widehat{E P V}_{t}(x)
$$

where $W_{t-1} \equiv B_{t-1}(t)+M_{t-1}+Q^{*} B_{t-1}(t+1)$ and $\widehat{E P V}_{t}(x) \equiv k+\tau_{t}-z_{t}+\sum_{i=1}^{\infty} \beta^{i} E_{t} x_{t+i}$. By pegging the bond price, the central bank forces the full adjustment to news about lower

estimates of a behavioral relation for fiscal policy and an equilibrium relation between surpluses and debt $[\operatorname{Li}(2011)]$. 
surpluses to occur through increases in the current price level, which revalue the outstanding nominal government liabilities. For an incremental change in surpluses, $d \widehat{E P V}_{t}(x)$, the change in the price level is

$$
d P_{t}=-\frac{W_{t-1}}{\left[\widehat{E P V}_{t}(x)\right]^{2}} d \widehat{E P V}_{t}(x)
$$

so the rise in the price level is increasing in total nominal government liabilities outstanding and decreasing in the initial market value of those liabilities.

A higher price level raises nominal money demand. To maintain the pegged bond price at $Q^{*}$, the central bank must expand the nominal money stock by $d M_{t}=k d P_{t}$, which ensures that the money market clears at $t$. It does this by buying outstanding bonds with newly issued $M_{t}$. With $Q^{*}$ pegged, this open-market purchase can occur in either one- or twoperiod bonds, to the same effect. As ever, characterizing monetary policy as controlling the nominal interest rate entails a supporting open-market policy.

Expressed in proportional changes, the equilibrium is

$$
\frac{d P_{t}}{P_{t}}=\frac{d M_{t}}{M_{t}}=-\frac{d \widehat{E P V}_{t}(x)}{\widehat{E P V}_{t}(x)}
$$

The supporting open-market policy is not the textbook case of $\Delta M_{t}=-\Delta B_{t}$, in which new money is swapped for bonds, dollar-for-dollar. Instead, given the new equilibrium price level from (30) and the associated new equilibrium level of money balances, $d M_{t}=k d P_{t}$, the new level of nominal bonds outstanding must be consistent with the government's flow budget constraint. Denote the face value of government bonds outstanding at $t$ by $\mathcal{B}_{t} \equiv$ $B_{t}(t+1)+Q^{*} B_{t}(t+2)$. In equilibrium, the change in $\mathcal{B}_{t}$ consistent with the government's budget constraint and the equilibrium in (31) may be expressed as

$$
\frac{d \mathcal{B}_{t}}{\mathcal{B}_{t}}=\left(\frac{k+\tau_{t}-z_{t}}{Q^{*} \mathcal{B}_{t} / P_{t}}\right) \frac{\widehat{d \widehat{E P V}_{t}}(x)}{\widehat{E P V}_{t}(x)}
$$

News at $t$ that primary surpluses will be lower in the future raises $P_{t}$. To maintain equilibrium in the money market and allow the short-term bond price to be pegged at $Q^{*}$, the central bank passively expands $M_{t}$ in proportion to the rise in prices. In general, this is not the end of the policy adjustments because the higher price level that arises from news about future surpluses leaves the government's budget out of balance by revaluing outstanding debt obligations. As (32) makes clear, in equilibrium the face value of government bonds may rise or fall - more or fewer bonds will be in the hands of the public in period $t$ - as a consequence 
of the news of lower future surpluses. If the current (modified) primary surplus $-k+\tau_{t}-z_{t}$-is positive, the face value of bonds declines; if it's negative, the face value rises.

The empirical implications of this equilibrium underscore the difficulties associated with drawing causal inferences from the patterns of correlation that a fiscal inflation produces. To summarize, news of lower future surpluses creates the following correlations:

- negative correlation between inflation and market value of initial government liabilities, $W_{t-1} / P_{t}$

- positive correlation between inflation and money growth;

- any correlation between nominal debt growth and inflation (or money growth);

- higher inflation and money growth predicts future fiscal deficits, contradicting the Granger-causality results of King and Plosser (1985).

Evidently, monetary policy behavior - the pegging of short bond prices - plays a central role in this equilibrium. But that role is not the traditional one of monetizing debt and there will be no evidence in time series data that inflation is being produced by high current budget deficits or open-market purchases of government bonds, although there will be strong evidence that inflation is proportional to money growth.

Future Inflation By pegging the short-term nominal rate in every period, the central bank also pegs the long-term (two-period) interest rate. This forces all adjustments to fiscal news into the current price level and leaves expected price levels unchanged. A different monetary policy can force all adjustments into future prices, leaving the current price level unchanged.

Rewrite equilibrium condition (28) as

$$
\frac{B_{t-1}(t)+M_{t-1}}{P_{t}}+\beta\left[B_{t-1}(t+1)+M_{t}\right] E_{t} \frac{1}{P_{t+1}}=\widetilde{E P V}_{t}(x)
$$

where $\widetilde{E P V}_{t}(x) \equiv(1+\beta) k+\tau_{t}-z_{t}+\tau_{t+1}-z_{t+1}+\sum_{i=2}^{\infty} \beta^{i} E_{t} x_{t+i} \cdot{ }^{12}$

We seek an equilibrium in which $d P_{t}=0$, implying that $d M_{t}=0$ also. In such an equilibrium, news that revises down the expected present value, $\widetilde{E P V}_{t}(x)$, affects expected inflation according to

$$
d\left(E_{t} \frac{P_{t}}{P_{t+1}}\right)=\frac{1}{\beta\left[\left(B_{t-1}(t+1)+M_{t}\right) / P_{t}\right]} d \widetilde{E P V}_{t}(x)
$$

\footnotetext{
${ }^{12}$ To obtain (33) we used $\beta E_{t} s_{t+1}=E_{t}\left[\left(M_{t+1}-M_{t}\right) / P_{t+1}\right]=\beta\left[k-M_{t} E_{t}\left(1 / P_{t+1}\right)\right]$.
} 
Lower expected primary surpluses produce higher expected inflation.

The central bank implements the equilibrium in which lower expected surpluses raise future, but not current, prices by adjusting the one-period nominal interest rate appropriately. First write the equilibrium change in expected prices in (34) in terms of $E_{t}\left(P_{t} / P_{t+1}\right)$ and note that the Euler equation implies that $Q_{t}(t+1)=\beta E_{t}\left(P_{t} / P_{t+1}\right)$. Monetary policy pushes into the future the inflationary consequences of anticipated fiscal expansions by setting policy as

$$
d Q_{t}(t+1)=\frac{1}{\left(\frac{B_{t-1}(t+1)+M_{t}}{P_{t}}\right)} \widehat{d E P V_{t}}(x)
$$

If the expected present value of surpluses falls, the central bank reduces the price of oneperiod bonds, raising the one-period nominal interest rate. That is, monetary policy leans against expected fiscal expansion.

At $t+1$, when the higher price level is realized, $M_{t+1}$ must rise proportionately. The equilibrium displays patterns of correlation analogous to those above and conventional empirical approaches to fiscal policy and inflation will have a difficult time finding evidence that fiscal expansions are inflationary. Inflation occurs at $t+1$, but surpluses can change at any $t+k, k \geq 0$, so there is no simple Granger-causal ordering between inflation and fiscal variables. Data will contain overwhelming support, however, for positive money growth/inflation correlation.

2.5 Regime F: Long-Term Government Debt Inflation dynamics become still richer when we posit that the government issues only consols, a perpetuity that never matures. ${ }^{13}$ The government's flow budget constraint is

$$
\frac{Q_{t} B_{t}}{P_{t}}+x_{t}=\frac{\left(1+Q_{t}\right) B_{t-1}}{P_{t}}
$$

We also have the Euler equation for consols

$$
Q_{t}=\beta E_{t} \frac{P_{t}}{P_{t+1}}\left(1+Q_{t+1}\right)
$$

Again, the economy has a constant endowment.

Iterate on the flow constraint, (36), impose (37) and the transversality condition, and combine the result with the flow budget constraint to yield the intertemporal equilibrium

\footnotetext{
${ }^{13}$ This exposition draws on Cochrane (2001, 2011c).
} 
condition

$$
\frac{\left(1+Q_{t}\right) B_{t-1}}{P_{t}}=\sum_{j=0}^{\infty} \beta^{j} E_{t} x_{t+j}=E P V_{t}(x)
$$

The intertemporal equilibrium condition implies a convenient expression linking, in equilibrium, the bond price, the current price level, and the expected present value of surpluses

$$
\frac{d\left(1+Q_{t}\right)}{1+Q_{t}}-\frac{d P_{t}}{P_{t}}=\frac{d E P V_{t}(x)}{E P V_{t}(x)}
$$

From (37), the price of the consol can be expressed in terms of the entire expected future path of inflation rates

$$
\begin{aligned}
Q_{t} & =\sum_{j=1}^{\infty} \beta^{j} E_{t} \frac{P_{t}}{P_{t+j}} \\
& =\sum_{j=0}^{\infty} E_{t}\left(\prod_{i=0}^{j} \frac{1}{R_{t+i}}\right)
\end{aligned}
$$

where $R_{t}$ is the one-period nominal interest rate controlled by the central bank. The associated short-term nominal bond is priced as $1 / R_{t}=\beta E_{t}\left(P_{t} / P_{t+1}\right)$.

Using (39), (40) and (41), a given percentage decrease in the expected present value of surpluses can be apportioned into any mix of current and expected inflation rates consistent with (38) and (40). Substituting (40) into (38) and denoting the inflation rate as $\pi_{t} \equiv P_{t} / P_{t-1}$ reveals that the expected present value of surpluses determines "total inflation," defined as the expected present value of inflation rates

$$
\frac{B_{t-1}}{P_{t-1}} \sum_{j=0}^{\infty} \beta^{j} E_{t}\left(\frac{1}{\prod_{k=0}^{j} \pi_{t+k}}\right)=E P V_{t}(x)
$$

Monetary policy behavior determines the precise pattern of expected inflation rates through its setting of current and expected short-term nominal interest rates. ${ }^{14}$

Consols, though not a realistic maturity structure for government bonds, help to make clear the range of possible inflation processes that a fiscal theory equilibrium can produce. First, inflation effects are larger when they are concentrated in only a few periods and smaller when they are spread over many periods. Second, because only the present value of inflation is pinned down by (38) and (40), news of lower future surpluses can generate any path

\footnotetext{
${ }^{14}$ Because in this policy regime the equilibrium price level is uniquely determined by (38), together with equilibrium $\left\{Q_{t}\right\}$, monetary policy may be treated as setting the sequence of short rates, $\left\{R_{t}\right\}$, exogenously in any pattern desired, without fear of generating indeterminacy of equilibrium.
} 
of expected inflation: it can rise or fall in various periods, so long as the present value of expected inflation adjusts to satisfy (42). Third, because many paths of the surplus are consistent with a given expected present value, the expected surplus can also rise or fall over various horizons, as long as the deliver the expected present value.

\section{How Fiscal Policy Can Undermine Monetary Control of In- FLATION}

This section examines situations in which fiscal policy can undermine monetary control of inflation. We provide three scenarios in which monetary policy may not be able to target inflation. These scenarios are by no means exhaustive, but serve to illustrate the extent to which monetary and fiscal policy must coordinate in order to effectively control the price level. One example draws on Davig, Leeper, and Walker (2010), Leeper (2011), and Leeper and Walker (2011) and assumes Regime $\mathrm{M}$ is operative until a fiscal limit is hit at date T. A fiscal limit is the point at which tax rates, either through political or economic constraints, can no longer adjust to passively raise future tax revenues. A second example introduces risky sovereign debt to show that a higher probability of default feeds directly into higher current inflation. The third scenario is a two-country monetary union in which one country follows Regime $\mathrm{F}$ with the central bank pegging the nominal interest rate. We demonstrate in this case that even if the other country implements Regime M, then inflation in the monetary union is determined by the Regime F country, regardless of the country's size. This analysis draws on work by Sims (1997), Bergin (2000), Dupor (2000), Daniel (2001) and Daniel and Shiamptanis (2011).

3.1 Fiscal Limit This section modifies the cashless model in section 2 by assuming the economy at some known future date $T$ reaches a fiscal limit. We starkly model the reluctance to increase taxes to stabilize debt in the face of growing transfer payments by assuming that at date $T$, taxes reach their maximum, $\tau^{\max } .^{15}$

Leading up to $T$, policy is in the active monetary/passive fiscal regime described above, but from date $T$ on, tax policy has no option but to become active, with $\tau_{t}=\tau^{\max }$ for $t \geq T$. If monetary policy remained active, neither authority would stabilize debt and debt would explode. Existence of a bounded equilibrium requires that monetary policy switch to being passive, which stabilizes debt. Table 2 summarizes the assumptions about policy behavior.

\footnotetext{
${ }^{15}$ In this model with lump-sum taxes there is no upper bound for taxes or debt, so long as debt does not grow faster than the real interest rate. But in a more plausible production economy, in which taxes distort behavior, there would be a natural fiscal limit - the peak of the Laffer curve. See Davig, Leeper, and Walker $(2010,2011)$ for further discussion and Bi (2011) for an application of an endogenous fiscal limit to the issue of sovereign debt default.
} 


\begin{tabular}{l|c|c} 
& $\begin{array}{c}\text { Regime } 1 \\
t=0,1, \ldots, T-1\end{array}$ & $\begin{array}{c}\text { Regime } 2 \\
t=T, T+1, \ldots\end{array}$ \\
\hline Monetary Policy & $R_{t}^{-1}=R^{*-1}+\alpha\left(\frac{P_{t-1}}{P_{t}}-\frac{1}{\pi^{*}}\right)$ & $R_{t}^{-1}=R^{*-1}$ \\
Tax Policy & $\tau_{t}=\tau^{*}+\gamma\left(\frac{B_{t-1}}{P_{t-1}}-b^{*}\right)$ & $\tau_{t}=\tau^{\max }$
\end{tabular}

Table 2: Monetary-Fiscal Policy Regimes Before and After the Fiscal Limit at Date $T$

We assume that government transfers evolve exogenously according to the stochastic process

$$
z_{t}=(1-\rho) z^{*}+\rho z_{t-1}+\varepsilon_{t}, \quad 0<\rho<1
$$

where $z^{*}$ is steady-state transfers and $\varepsilon_{t}$ is a serially uncorrelated shock with $E_{t} \varepsilon_{t+1}=0$.

The intertemporal equilibrium condition now is the sum of two distinct parts

$$
\frac{B_{0}}{P_{0}}=E_{0} \sum_{j=1}^{T-1} \beta^{j} s_{j}+E_{0} \sum_{j=T}^{\infty} \beta^{j} s_{j}
$$

where the function for the primary surplus, $s_{t}$, changes at the fiscal limit according to

$$
s_{t}= \begin{cases}\tau^{*}-\gamma\left(B_{t-1} / P_{t-1}-b^{*}\right)-z_{t}, & t=0,1, \ldots, T-1 \\ \tau^{\max }-z_{t}, & t=T, \ldots, \infty\end{cases}
$$

Expression (44) decomposes the value of government debt at the initial date into the expected present value of surpluses leading up to the fiscal limit and the expected present value of surpluses after the limit has been hit. Date $T$ is assumed to be known. ${ }^{16}$

Evaluating the second part of (44) and letting $\tau^{\max }=\tau^{*}$, after the limit is hit at $T$

$$
\begin{aligned}
E_{0} \sum_{j=T}^{\infty} \beta^{j} s_{j} & =E_{0}\left(\frac{B_{T-1}}{P_{T-1}}\right) \\
& =\frac{\beta^{T}}{1-\beta}\left(\tau^{*}-z^{*}\right)-\frac{(\beta \rho)^{T}}{1-\beta \rho}\left(z_{0}-z^{*}\right)
\end{aligned}
$$

\footnotetext{
${ }^{16}$ Davig, Leeper, and Walker $(2010,2011)$ and Leeper and Walker (2011) relax this assumption by modeling $T$ is a random variable. In this case, there are expectational spillover effects which further strengthen the arguments made in this section.
} 
The first part of (44) is given by

$$
\begin{aligned}
E_{0} \sum_{j=1}^{T-1} \beta^{j} s_{j} & =\sum_{j=1}^{T-1}\left(\frac{\beta}{1-\gamma \beta}\right)^{j}\left[\left(\tau^{*}-\gamma b^{*}\right)-E_{0} z_{j}\right] \\
& =\left(\tau^{*}-\gamma b^{*}-z^{*}\right) \sum_{j=1}^{T-1}\left(\frac{\beta}{1-\gamma \beta}\right)^{j}-\left(z_{0}-z^{*}\right) \sum_{j=1}^{T-1}\left(\frac{\beta \rho}{1-\gamma \beta}\right)^{j}
\end{aligned}
$$

Pulling together (46) and (47) yields equilibrium real debt at date $t=0$ as a function of fiscal parameters and the date 0 realization of transfers

$$
\begin{aligned}
\frac{B_{0}}{P_{0}} & =\left(\tau^{*}-\gamma b^{*}-z^{*}\right) \sum_{i=1}^{T-1}\left(\frac{\beta}{1-\gamma \beta}\right)^{i}-\left(z_{0}-z^{*}\right) \sum_{i=1}^{T-1}\left(\frac{\beta \rho}{1-\gamma \beta}\right)^{i} \\
& +\left(\frac{\beta}{1-\gamma \beta}\right)^{T-1}\left[\frac{\beta^{T}}{1-\beta}\left(\tau^{\max }-z^{*}\right)-\frac{(\beta \rho)^{T}}{1-\beta \rho}\left(z_{0}-z^{*}\right)\right]
\end{aligned}
$$

This expression determines the equilibrium value of debt at $t=0$ and, by extension, at each date in the future. We make three observations. First, this economy will not exhibit Ricardian equivalence for $\tau^{\max }$ sufficiently small and sufficiently large increases in transfers. In the derivations above, we set $\tau^{\max }=\tau^{*}$, but a sufficient condition for our results to go through is given by $\tau^{\max }<\tau^{*}+\gamma\left(B_{t-1} / P_{t-1}-b^{*}\right)$ for all realizations of $z_{t}$. The fiscal rule after $T$ implies that positive innovations to transfers will not be entirely offset by future changes in tax rates. Only in the absence of the fiscal limit or if $\tau^{\max }$ is sufficiently large will Ricardian equivalence hold. This occurs despite the fact that in the absence of a fiscal limit such a tax rule delivers Ricardian equivalence, as it did in section 2.1. Second, higher transfers at time $0, z_{0}$, which portend a higher future path of transfers because of their positive serial correlation, reduce the value of debt. This occurs for the reasons that section 2.2 lays out: higher expected government expenditures reduce the backing and, therefore, the value of government liabilities. Finally, how aggressively tax policy responds to debt before hitting the fiscal limit, $\gamma$, matters for the value of debt. The Ricardian equivalence that exists in the permanent active monetary/passive tax regime implies that the timing of taxation is irrelevant: how rapidly taxes stabilize debt has no bearing on the value of debt so long as debt is sustainable.

To calculate the price level at $t=0$, use the government's flow budget constraint and the fact that $s_{0}=\tau_{0}-z_{0}$, with taxes following the rule shown in table 2 to solve for $P_{0}$ :

$$
P_{0}=\frac{R_{-1} B_{-1}}{b_{0}+\tau_{0}-z_{0}}
$$


Given $R_{-1} B_{-1}>0$, (49) yields a unique $P_{0}>0$. Entire sequences of equilibrium $\left\{P_{t}, R_{t}^{-1}\right\}_{t=0}^{\infty}$ are solved recursively: having solved for $B_{0} / P_{0}$ and $P_{0}$, obtain $R_{0}$ from the monetary policy rule in table 2 , and derive the nomimal value of debt. Then use (48) redated at $t=1$ to obtain equilibrium $B_{1} / P_{1}$ and the government budget constraint at $t=1$ to solve for $P_{1}$ using (49) redated at $t=1$, and so forth.

The equilibrium price level has the same features as it does under the passive monetary/active tax regime in section 2.2. This is because forward-looking agents know that higher current or expected transfers are not backed in present-value terms by expected taxes. This, in turn, raises household wealth which increases the demand for goods and drives up the price level (reducing the value of debt to an equilibrium value). Similarities between this equilibrium and that in section 2.2 stem from the fact that price-level determination is driven by beliefs about policy in the long run. From $T$ on, this economy is identical to the fixed-regime passive monetary/active fiscal policies economy and it is beliefs about long-run policies that determine the price level. Alternatively, one may think of price level determination in this economy as coming from agents learning about (44), along the lines of Eusepi and Preston (2011). In such an economy, agents coordinate beliefs on long-run policies and the equilibrium would be one in which fiscal policy is active and monetary policy is passive. Of course, before the fiscal limit the two economies are quite different and the behavior of the price level will also be different.

In this environment, monetary policy continues to determine expected inflation while fiscal policy determines realizations. Combining (4) with the monetary policy rule in table 2 , we obtain an expression in expected inflation

$$
E_{t}\left(\frac{P_{t}}{P_{t+1}}-\frac{1}{\pi^{*}}\right)=\frac{\alpha}{\beta}\left(\frac{P_{t-1}}{P_{t}}-\frac{1}{\pi^{*}}\right)
$$

for $t \geq 0$. As argued above, the equilibrium price level sequence, $\left\{P_{t}\right\}_{t=0}^{\infty}$ is determined by versions of (48) and (49) for each date $t$, so (50) describes the evolution of expected inflation. Given equilibrium $P_{0}$ from (49) and an arbitrary $P_{-1}$ - arbitrary because the economy starts at $t=0$ and cannot possibly determine $P_{-1}$, regardless of policy behavior- $(50)$ shows that $E_{0}\left(P_{0} / P_{1}\right)$ grows relative to the initial inflation rate. In fact, throughout the active monetary policy/passive fiscal policy phase, for $t=0,1, \ldots, T-1$, expected inflation grows at the rate $\alpha \beta^{-1}>1$. In periods $t \geq T$ monetary policy pegs the nominal interest rate at $R^{*}$, and expected inflation is constant: $E_{t}\left(P_{t} / P_{t+1}\right)=\left(R^{*} \beta\right)^{-1}=1 / \pi^{*}$.

The implications of the equilibrium laid out in equations (48), (49), and (50) for government debt, inflation, and the anchoring of expectations on the target values $\left(b^{*}, \pi^{*}\right)$ are most clearly seen in a simulation of the equilibrium. Figure 2 contrasts the paths of the debt-GDP 
ratio from two models: the fixed (permanent) passive monetary/active tax regime in section 2.2 - dashed line - and the present model in which an active monetary/passive tax regime is in place until the economy hits the fiscal limit at date $T$, when policies switch permanently to a passive monetary/active tax combination - solid line. ${ }^{17}$ The fixed regime displays stable fluctuations of real debt around the 50 percent steady state debt-GDP, which, of course, the other model also produces once it hits the fiscal limit. Leading up to the fiscal limit, however, it is clear that the active monetary/passive tax policy combination does not keep debt as close to target.

Expected inflation evolves according to (50). Since leading up the fiscal limit monetary policy is active, with $\alpha>1 / \beta$, there is no tendency for expected inflation to be anchored on the inflation target. Figure 3 plots the inflation rate from the fixed-regime model in section 2.2 - dashed line - and from the present model - solid line - along with expected inflation from the present model - dotted dashed line. Inflation in the fixed regime fluctuates around $\pi^{*}$ and, of course, with the pegged nominal interest rate, expected inflation is anchored on target. But in the period leading up to the fiscal limit, the price level is being determined primarily by fluctuations in the real value of debt which, as figure 2 shows, deviates wildly from $b^{*}$. Expected inflation in that period, though not independent of the inflation target, is certainly not anchored by the target. Instead, under active monetary policy, the deviation of expected inflation from target grows with the deviation of actual inflation from target in the previous period. The figure shows how equation (50) makes expected inflation follow actual inflation, with active monetary policy amplifying movements in expected inflation.

To underscore the extent to which inflation is unhinged from monetary policy, even in the active monetary/passive tax regime before the fiscal limit, suppose that tax policy reacts more aggressively to debt. Normally, this would return debt to target more rapidly. But in the presence of a fiscal limit, a higher value of $\gamma$ can have unexpected consequences. Expression (48) makes clear that raising $\gamma$ amplifies the effects of transfers shocks on debt. A more volatile value of debt, in turn, translates into more volatile actual and expected inflation. Figures 4 and 5 show this result by repeating the previous figures, but with a passive tax policy that responds more strongly to debt ( $\gamma$ is raised from 0.10 to 0.15 ).

Figures 4 and 5 also illustrate a general phenomenon: as the economy approaches the fiscal limit at time $T$, the equilibrium with different tax policies converge. As we also see in figures 2 and 3, of course, as time approaches $T$, the equilibrium also converges to the fixed-regime economy.

\footnotetext{
${ }^{17}$ Figures 2 through 5 use the following calibration. Leading up to the fiscal limit, $\alpha=1.50$ and $\gamma=0.10$ and at the limit and in the fixed-regime model, $\alpha=\gamma=0.0$. We assume steady state values $\tau^{*}=0.19$, $z^{*}=0.17, \pi^{*}=1.02$ (gross inflation rate) and we assume $1 / \beta=1.04$ so that $b^{*}=0.50$. The transfers process has $\rho=0.90$ and $\sigma=0.003$. Identical realizations of transfers were used in all the figures.
} 


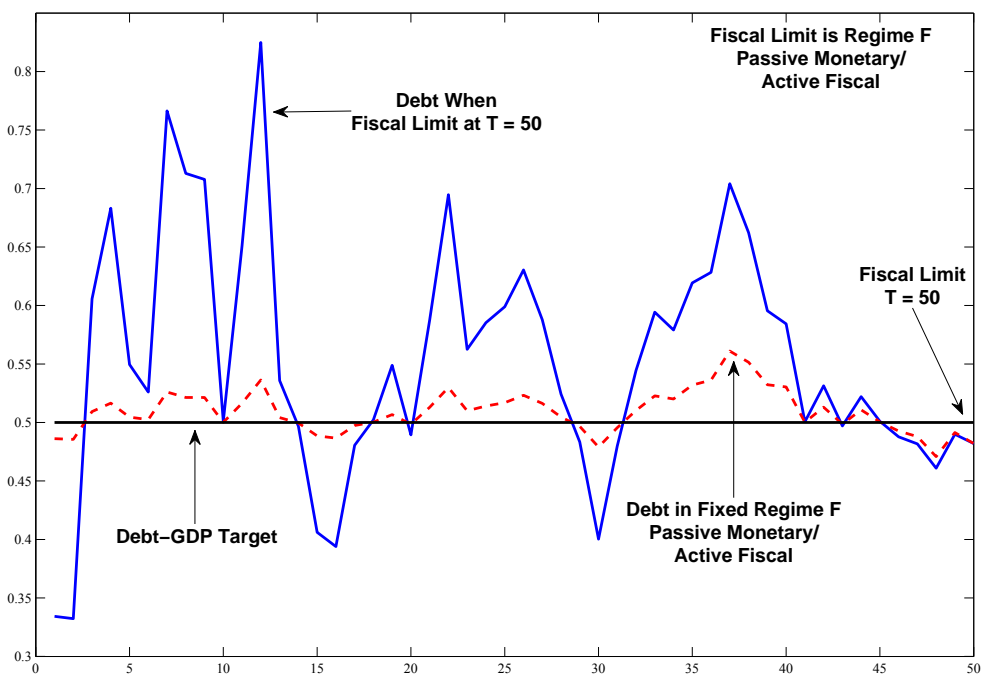

Figure 2: Debt-GDP ratios for a realization of transfers for two models: fixed passive monetary/active tax regime in section 2.2 - dashed line - and model in which an active monetary/passive tax regime is in place until the economy hits the fiscal limit at date $T$, when policies switch permanently to passive monetary/active tax - solid line.

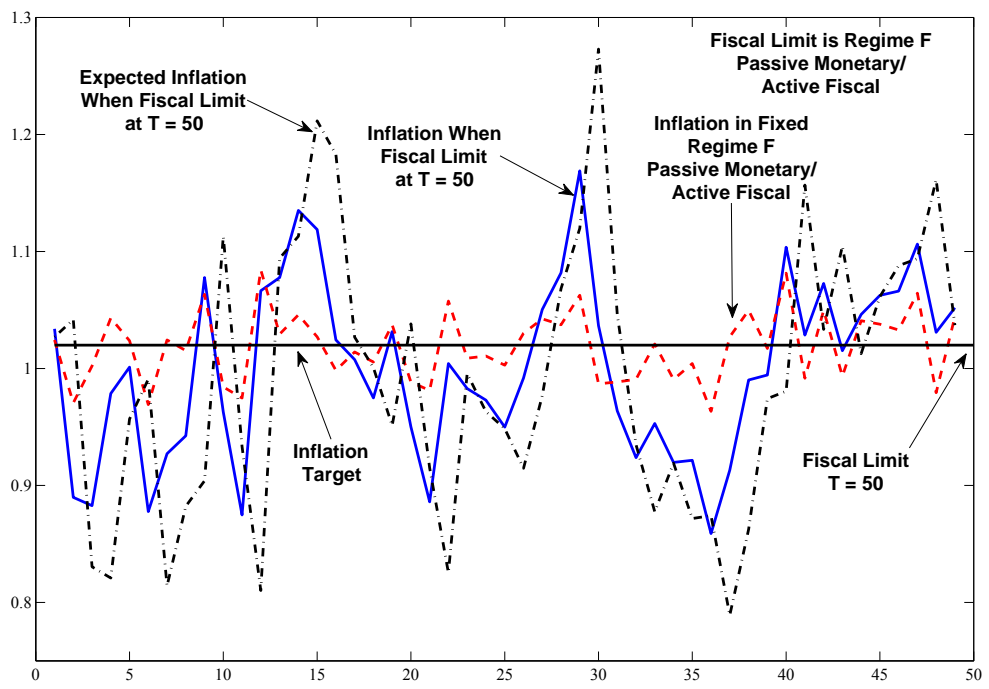

Figure 3: Inflation for a realization of transfers for two models: fixed passive monetary/active tax regime in section 2.2 - dashed line - and model in which an active monetary/passive tax regime is in place until the economy hits the fiscal limit at date $T$, when policies switch permanently to passive monetary/active tax - solid line; expectation of inflation from present model-dotted dashed line. 


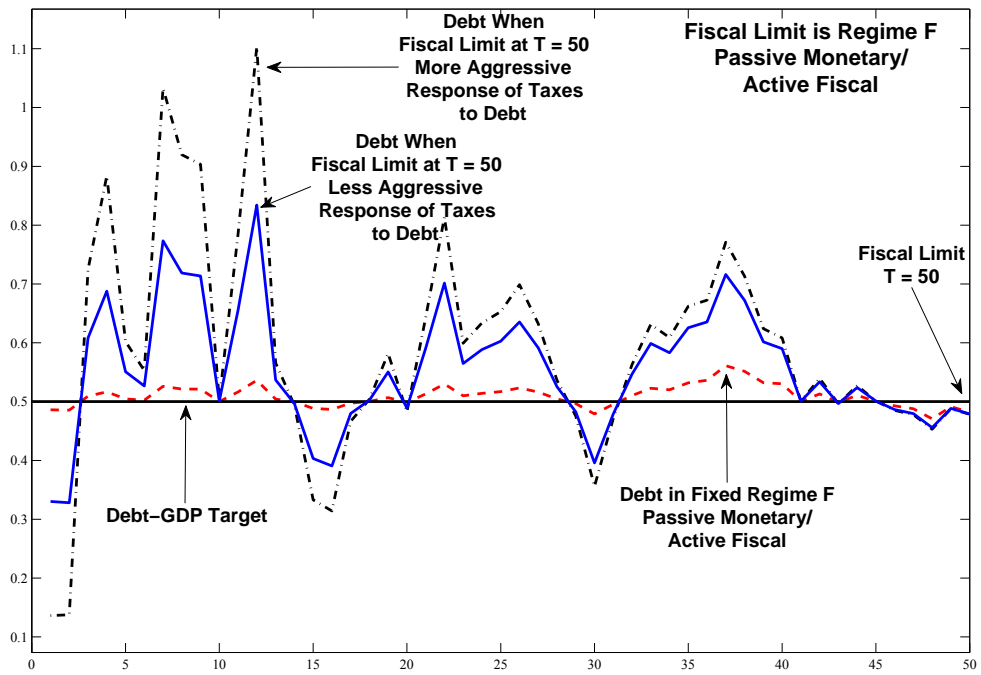

Figure 4: Debt-GDP ratios for two settings of tax policy: fixed passive monetary/active fiscal regime in section 2.2- dashed line - the active monetary/passive fiscal regime before the fiscal limit at date $T$ with weaker response of taxes to debt $(\gamma=0.10)$ - solid line - the active monetary/passive fiscal regime before the fiscal limit at date $T$ with stronger response of taxes to debt $(\gamma=0.15)$ - dotted dashed line.

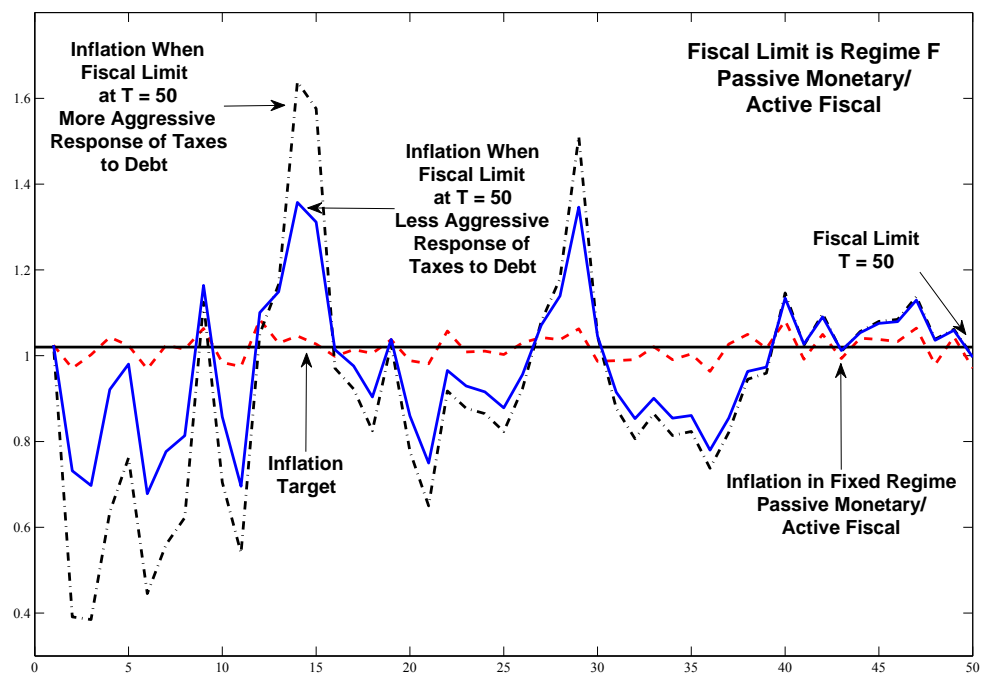

Figure 5: Inflation for two settings of tax policy: actual inflation in fixed passive monetary/active fiscal regime in section 2.2 - dashed line expected inflation in the active monetary/passive fiscal regime before the fiscal limit at date $T$ with weaker response of taxes to $\operatorname{debt}(\gamma=0.10)$ - solid line - expected inflation in the active monetary/passive fiscal regime before the fiscal limit at date $T$ with stronger response of taxes to debt $(\gamma=0.15)$ - dotted dashed line. 
An analogous exercise for monetary policy illustrates its impotence when there is a fiscal limit. A more hawkish monetary policy stance, higher $\alpha$, has no effect whatsoever on the value of debt and inflation: $\alpha$ does not appear in expression (48) for real debt or expression (49) for the price level. More hawkish monetary policy does, however, amplify the volatility of expected inflation, as the evolution of expected inflation, equation (50), shows.

Because monetary policy loses control of inflation after the fiscal limit is reached, forwardlooking behavior implies it also loses control of inflation before the fiscal limit is hit. By extension, changes in fiscal behavior in the period leading up to the limit affect both the equilibrium inflation process and the process for expected inflation.

3.2 Risky Sovereign Debt and Inflation Bi, Leeper, and Leith (2010) explore how the possibility of sovereign debt default can further complicate the central bank's efforts to control inflation. Here we show this basic result in a simple example.

Consider a constant endowment, cashless economy in which the equilibrium real interest rate, $1 / \beta$, is also constant. Government default is the sole source of uncertainty and, for the current purposes, the decision to default by the fraction $\delta_{t} \in[0,1]$ on outstanding debt is exogenous and follows a known stochastic process. Let $R_{t}$ be the gross risky rate of return on nominal government debt and $\pi_{t}=P_{t} / P_{t-1}$ be the inflation rate. Household optimization yields the Fisher relation

$$
\frac{1}{R_{t}}=\beta E_{t}\left[\frac{1-\delta_{t+1}}{\pi_{t+1}}\right]
$$

while trade in risk-free bonds (assumed to be in zero net supply) gives an analogous relation for the risk-free interest rate, $R_{t}^{f}$,

$$
\frac{1}{R_{t}^{f}}=\beta E_{t}\left[\frac{1}{\pi_{t+1}}\right]
$$

The government's budget constraint is

$$
\frac{B_{t}}{P_{t}}+s_{t}=\frac{\left(1-\delta_{t}\right)}{\pi_{t}} R_{t-1} \frac{B_{t-1}}{P_{t-1}}
$$

where $s_{t}$ is the primary surplus. Write this constraint at $t+1$, take expectations conditional on information at $t$, impose the Euler equation $\beta^{-1}=E_{t}\left(1-\delta_{t+1}\right) R_{t} / \pi_{t+1}$, and solve for $B_{t} / P_{t}$ to yield

$$
\frac{B_{t}}{P_{t}}=\beta E_{t} \frac{B_{t+1}}{P_{t+1}}+\beta E_{t} s_{t+1}
$$

When the real interest rate is fixed, both the nominal rate and the inflation rate reflect default, so that the expected default rate drops out once expectations are taken. This 
implies that only surprises in default directly affect the evolution of real government debt in this flexible-price endowment economy. In light of this, we obtain, by iterating on (54) and imposing the household's transversality condition

$$
\frac{B_{t}}{P_{t}}=\sum_{j=1}^{\infty} \beta^{j} E_{t} s_{t+j}
$$

Expression (55) is the usual intertemporal equilibrium condition that equates the value of government debt to the expected present value of "cash flows," which are primary surpluses.

Fiscal policy sets the surplus in order to stabilize the post-default value of government debt

$$
s_{t}-s^{*}=\gamma\left[\left(1-\delta_{t}\right) \frac{B_{t-1}}{P_{t-1}}-b^{*}\right]
$$

where $s^{*}$ and $b^{*}$ are target and steady state values for the surplus and real debt and $b_{t-1}=$ $B_{t-1} / P_{t-1}$.

Substituting (56) into (53) and taking expectations at time $t$ yields the evolution of expected debt

$$
E_{t} b_{t+1}+\left(s^{*}-\gamma b^{*}\right)=\left[\beta^{-1}-\gamma\left(1-E_{t} \delta_{t+1}\right)\right] b_{t}
$$

One result that emerges immediately from (57) is that stability of the debt process in the face of debt default requires that

$$
\gamma>\frac{\beta^{-1}-1}{1-E_{t} \delta_{t+1}}
$$

a condition that potentially is far more demanding than the usual one that $\gamma>\beta^{-1}-1$, particularly when substantial default rates are possible. Here stability also has the unusual property of being time varying, changing with the conditional expectation of default. Provided this condition is fulfilled, however, fiscal policy remains passive and capable of stabilizing the real value of government debt.

Following Uribe (2006) and Schabert (2010), we assume that monetary policy sets the rate on short-term government debt, the risky nominal interest rate, $R_{t}$, according to a simple Taylor rule

$$
\frac{1}{R_{t}}=\frac{1}{R^{*}}+\alpha\left(\frac{1}{\pi_{t}}-\frac{1}{\pi^{*}}\right)
$$

Monetary policy targets inflation by setting $\alpha / \beta>1$. Aside from being the dominant rule in the literature, in the context of our cashless model it is natural for monetary policy to be implemented by varying the contractual interest rate on government debt, rather than the risk-free interest rate on private debt, over which the government has no direct control and which is in zero net supply in equilibrium. More generally, in the transmission from 
the very short-term rates targeted through open-market operations to the wider economy and, ultimately inflation, the central bank would expect to see a significant degree of pass through to the contractual interest rates employed throughout the economy. ${ }^{18}$ Indeed, since government bonds typically form the collateral for the repo contracts undertaken by central banks, it is inevitable that without an offsetting policy adjustment, the policy rates pick up some of the default risk. ${ }^{19}$

When monetary policy controls the risky interest rate, $R_{t}$, default influences the ability of the monetary authority to target inflation, even if fiscal policy remains passive and monetary policy is active. To see this, combine the monetary policy rule in (59) with the Fisher relation to yield the dynamic equation for inflation

$$
\frac{1}{\pi_{t}}-\frac{1}{\pi^{*}}=\frac{\beta}{\alpha} E_{t}\left(\frac{1-\delta_{t+1}}{\pi_{t+1}}-\frac{1}{\pi^{*}}\right)
$$

which now depends on the expected default rate.

Active monetary policy implies that the unique locally bounded solution for inflation is

$$
\frac{1}{\pi_{t}}=\frac{1}{\pi^{*}}\left(1-\frac{\beta}{\alpha}\right)\left\{1+E_{t} \sum_{i=1}^{\infty}\left(\frac{\beta}{\alpha}\right)^{i} \prod_{j=1}^{i}\left(1-\delta_{t+j}\right)\right\}
$$

In the absence of default, $\delta_{t} \equiv 0$, monetary policy achieves its inflation target exactly, $\pi_{t}=\pi^{*}$. Higher expected default rates in the future raise current inflation. The farther into the future default is expected, the more it is discounted by $\beta / \alpha<1$, and the smaller is its impact on inflation at time $t$. Notice also that if the default rate is constant, $\delta_{t} \equiv \delta \in[0,1]$, then more aggressive monetary policy enhances the central bank's control of inflation. A constant default rate yields the solution for inflation

$$
\pi_{t}=\pi^{*}\left[\frac{1-(1-\delta) \frac{\beta}{\alpha}}{1-\frac{\beta}{\alpha}}\right]
$$

so that $\pi_{t} \rightarrow \pi^{*}$ as $\alpha \rightarrow \infty$. A more aggressive monetary policy response to inflation reduces the inflationary consequences of default. Importantly, the effectiveness of monetary policy

\footnotetext{
${ }^{18}$ Empirical evidence suggests that the rate at which policy interest rates pass through to bank interest rates is quite high - about 90 percent within a quarter [Gambacorta (2008)]. We are implicitly assuming similarly high rates of pass through to government bond yields.

${ }^{19}$ Sims (2008) emphasizes that the unconventional operations of many central banks - particularly the Fed and the ECB - in recent years have made the central banks' balance sheets riskier. If foreign reserves are an important component of the bank's assets, as for the ECB, then surprise appreciation of the euro devalues its assets relative to its liabilities. The Fed's increased holdings of long-term Treasuries expose its balance sheet to more interest-rate risk than normal. Riskiness is exacerbated if the central bank is not assured that the fiscal authority will back it in times of large declines in asset values.
} 
is conditional on fiscal policy behaving passively.

Finally, consider a stylized experiment. At time $t$ news arrives that raises the expected default rate at $t+1, E_{t} \delta_{t+1}>0$, but all subsequent expected default rates are zero, $E_{t} \delta_{t+j}=0$ for $j>1$. Then (61) reduces to

$$
\pi_{t}=\pi^{*}\left[\frac{1}{1-\frac{\beta}{\alpha} E_{t}\left(\delta_{t+1}\right)}\right]>\pi^{*}
$$

and again we see that higher expected default raises inflation, but the extent to which it does so is mitigated by a more aggressive monetary response to inflation in the form of a higher $\alpha$.

The source of this inflationary response to default can be seen in contrasting the interest rate rules when defined in terms of risky and risk-free interest rates. A risk-free rule, coupled with a passive fiscal policy, can successfully target inflation. To see why the rule defined in terms of the risky-rate cannot, it is helpful to return to the simple case where the default rate is constant, $\delta_{t} \equiv \delta \in[0,1]$, so that $\frac{1}{R_{t}}=\frac{1-\delta}{R_{t}^{f}}$. Rewrite (59) in terms of the risk-free rate as

$$
\frac{1}{R_{t}^{f}}=\frac{1}{R^{*}}+\frac{\alpha}{1-\delta}\left[\frac{1}{\pi_{t}}-\left(\frac{1}{\pi^{*}}-\frac{\delta}{\alpha R^{*}}\right)\right]
$$

The monetary policy rule defined in terms of the risky rate of interest can be transformed into a rule of the same form as that defined in terms of the risk-free rate, but with two important differences. First, default does not make monetary policy less active; in fact, it raises the coefficient on excess inflation, $\frac{\alpha}{1-\delta}>\alpha$. Second, default raises the effective inflation target from $\pi^{*}$ to $\frac{\pi^{*}}{1-\delta \beta / \alpha}$. Intuitively, a higher rate of default creates partial monetary policy accommodation: in the presence of default, the monetary authority must allow the risky rate of interest to rise to induce bondholders to continue holding the stock of government bonds. Given the monetary policy rule, the monetary authority will not raise interest rates without a rise in inflation. Bondholders attempt to sell bonds, increasing aggregate demand as they try to increase their consumption paths. This behavior pushes up the price level until bondholders are being compensated for their default risk and inflation and interest rates are consistent with the monetary rule. Stronger responsiveness of policy to inflation, higher $\alpha$, reduces the effective rise in the inflation target needed to achieve the rise in interest rates desired by bondholders. ${ }^{20}$

As a general proposition, the possibility of default can undermine the central bank's con-

\footnotetext{
${ }^{20} \mathrm{As} \mathrm{Bi}$, Leeper, and Leith (2010) note, monetary policy can regain its control of inflation through a policy rule that allows the central bank to react directly to the possibility of default, but such a rule is anathema to many central bankers.
} 
trol of inflation: there is a tight connection between expected default rates and inflation, as in Uribe (2006), but the mechanism differs from Uribe's. Uribe obtains his result through a standard fiscal theory of the price level mechanism by coupling an active monetary policy rule like (59) with an active fiscal rule akin to setting $\gamma=0$ in (56), just as in Loyo (1999) and, more recently, Sims (2011). Such analyses echo the logic of Sargent and Wallace's (1981) unpleasant arithmetic, where the fiscal consequences of a tight monetary policy can ultimately generate higher inflation because fiscal policy does not adjust to stabilize government debt. In contrast, the present result stems from the monetary policy response to default, but where the policy rule remains active and fiscal policy passive. Although there is a positive link between default and inflation, that link differs from existing results in crucial ways. For example, in Uribe (2006) delaying default supports unstable inflation dynamics for longer, making it more difficult for the monetary authority to hit its inflation target. In this active monetary/passive fiscal regime, though, the impact of future default on prices is discounted so that delaying default reduces the immediate inflationary consequences of default. In Uribe's setup, raising $\alpha$ further destabilizes inflation dynamics and moves the economy farther from its inflation target. More active monetary policy in Bi, Leeper and Leith's (2010) environment reduces deviations from the inflation target due to default.

3.3 Monetary Union The example in section 3.1 shows that the inability of policy makers to commit to a particular policy stance in the future has repercussions today. We now provide an example of an economy in which fiscal authorities in two countries in a monetary union are unable (or unwilling) to commit to passive fiscal behavior. It turns out that it takes only one country to deviate in order for the fiscal theory of the price level to emerge in the monetary union. The exposition simplifies the setup in Bergin (2000).

Consider two symmetric countries in a monetary union. One simplification of Bergin is to consider a cashless economy and another is to assume a constant world endowment of goods, $y_{t}=y_{1, t}+y_{2, t}=y$ for all $t$. A representative household in country $j$ maximizes

$$
E_{0} \sum_{t=0}^{\infty} \beta^{t} u\left(c_{j, t}\right)
$$

subject to

$$
c_{j, t}+\frac{B_{j, t}}{P_{t}}+\tau_{j, t}=y_{j, t}+z_{j, t}+\frac{R_{t-1} B_{j, t-1}}{P_{t}}
$$

Countries retain fiscal sovereignty in the sense that they set taxes, $\tau_{j, t}$, and transfers, $z_{j, t}$, independently. But there is a common price level, $P_{t}$, and a common one-period nominal interest rate, $R_{t}$, across the economies. A common price level implicitly assumes that all 
goods are traded and purchasing power parity holds. Below we describe how the single central bank sets $R_{t}$ each period.

Country $j$ 's government chooses policies to satisfy the flow budget constraint

$$
\frac{D_{j, t}}{P_{t}}+\tau_{j, t}+v_{j, t}=z_{j, t}+\frac{R_{t-1} D_{j, t-1}}{P_{t}}
$$

where $v_{j, t}$ is lump-sum transfers received from the common central bank.

The central bank buys and sells bonds, $B_{m, t}$, to implement its interest rate policies. The bank does not levy taxes or issue debt. Interest earnings from its portfolio holdings, $v_{1, t}$ and $v_{2, t}$, are rebated to the countries' national governments. The central bank's budget constraint is

$$
\frac{B_{m, t}}{P_{t}}+v_{1, t}+v_{2, t}=\frac{R_{t-1} B_{m, t-1}}{P_{t}}
$$

The Euler equation from household $j$ 's optimization is

$$
u^{\prime}\left(c_{j, t}\right)=\beta R_{t} E_{t} \frac{P_{t}}{P_{t+1}} u^{\prime}\left(c_{j, t+1}\right)
$$

Households also have the transversality condition

$$
\lim _{T \rightarrow \infty} \beta^{T} E_{t} u^{\prime}\left(c_{j, t+T}\right) \frac{B_{j, t+T}}{P_{t+T}}=0
$$

Goods and bond market clearing conditions are

$$
\begin{aligned}
c_{1, t}+c_{2, t} & =y_{1, t}+y_{2, t}=y \\
B_{1, t}+B_{2, t}+B_{m, t} & =D_{1, t}+D_{2, t}
\end{aligned}
$$

Although not strictly necessary for an equilibrium, we follow Sims (1997) and Bergin (2000) in imposing that each individual government must choose policies that are consistent with individual solvency. ${ }^{21}$

Assume that preferences are quadratic, as in Bergin (2000): $u\left(c_{j, t}\right)=c_{j, t}-\frac{a}{2} c_{j, t}^{2}$ for each $j=1,2$. Then with a constant worldwide endowment of goods, adding the Euler equations

\footnotetext{
${ }^{21}$ Woodford (1998b) observes that private optimizing behavior imposes only that the sum $D_{1, t}+D_{2, t}$ would satisfy transversality. In this case, debt issued by one country can grow exponentially as long as the other country is willing to buy that debt without limit and without any expectation of being repaid. Sims (1997) points out that any effort to rationalize government policies would lead immediately to transversality conditions for $D_{j, t}$ individually: it would not be politically optimal for a country to extend unlimited loans to another member country. An analogous argument applies to rule out overaccumulation of debt by the central bank.
} 
in (68) for $j=1,2$ implies the simple Fisher relation

$$
\frac{1}{R_{t}}=\beta E_{t} \frac{P_{t}}{P_{t+1}}
$$

and applying (68) to each $j$, country-specific consumptions are random walks

$$
\begin{aligned}
& c_{1, t}=E_{t} c_{1, t+1} \\
& c_{2, t}=E_{t} c_{2, t+1}
\end{aligned}
$$

Imposing equilibrium, the Fisher relation, and government flow budget constraints on iterated versions of (66) yields two country-specific intertemporal equilibrium conditions

$$
\begin{aligned}
& \frac{R_{t-1} D_{1, t-1}}{P_{t}}=\sum_{j=0}^{\infty} \beta^{j} E_{t}\left[\tau_{1, t+j}+v_{1, t+j}-z_{1, t+j}\right] \\
& \frac{R_{t-1} D_{2, t-1}}{P_{t}}=\sum_{j=0}^{\infty} \beta^{j} E_{t}\left[\tau_{2, t+j}+v_{2, t+j}-z_{2, t+j}\right]
\end{aligned}
$$

and an analogous intertemporal equilibrium condition that stems from private and central bank behavior

$$
\frac{R_{t-1} B_{m, t-1}}{P_{t}}=\sum_{j=0}^{\infty} \beta^{j} E_{t}\left[v_{1, t+j}+v_{2, t+j}\right]
$$

Consider a mix of monetary and fiscal policies in which the central bank pegs the nominal interest rate at $R_{t}=R^{*}$ for all $t$, while country 1 sets the primary surplus, $x_{1, t}=\left\{\tau_{1, t}-z_{1, t}\right\}$, exogenously and country 2 makes its primary surplus, $x_{2, t}$, strongly responsive to the state of its government debt

$$
x_{2, t}-x_{2}^{*}=\gamma\left(\frac{D_{2, t-1}}{P_{t-1}}-b_{2}^{*}\right)
$$

where $x_{2}^{*}$ is the steady state primary surplus and $b_{2}^{*}$ is the steady state value of government debt in country 2. By setting $\gamma>1 / \beta-1$, the government in country 2 adjusts future surpluses in response to deviations of debt from $b_{2}^{*}$ by enough to retire debt back to steady state.

Two results immediately emerge. First, if $\left\{x_{1, t}\right\}$ is exogenous and rebates from the central bank to the government, $\left\{v_{1, t}\right\}$, are independent of the state of government debt in country 1 , then the worldwide price level, $P_{t}$, is determined by equilibrium condition (71). At time $t, R_{t-1} D_{1, t-1}$ is predetermined and the expected present value of primary surpluses plus rebates are independent of $P_{t}$, so the price level must adjust to ensure that (71) holds. News of lower taxes or rebates or of higher transfers payments, reduces the value of country 1's 
debt, inducing agents in country 1 to substitute out of bonds and into consumption goods. This higher demand for goods raises the price level until agents are content to buy their initial consumption baskets.

In turn, a higher price level reduces the value of country 2's debt and, via the surplus rule in (74), reduces expected surpluses in that country. Thus, fiscal disturbances in country 1 spill over to country 2 through general equilibrium effects on the price level. The quantitative importance of these spillover effects depend upon the size of the tax cut or transfer payment in country $1 .^{22}$

Second, if the central bank determines rebates to member countries as a function of each country's fiscal stance - the value of outstanding debt - then (71) no longer imposes any restrictions on the equilibrium price level, even if country 1 continues to maintain exogenous primary surpluses. To uniquely determine the price level, the central bank must shift from pegging the nominal interest rate to targeting the inflation rate. It can do this by setting the nominal rate according to

$$
\frac{1}{R_{t}}=\frac{1}{R^{*}}+\alpha\left(\frac{P_{t-1}}{P_{t}}-\frac{1}{\pi^{*}}\right)
$$

where $\pi^{*}$ is the inflation target and $\alpha>1 / \beta$ to ensure a unique, stable inflation process.

Although this policy mix delivers a unique bounded equilibrium, it carries an important distributional message. Efforts by the central bank to reduce inflation will translate into higher values of debt in each country - conditions (71) and (72). Country 2, which is following the surplus rule in (74), will need to raise future surpluses. Country 1, which continues to set primary surpluses exogenously, now requires a relatively larger rebate from the central bank. As condition (73) makes clear, a higher rebate to country 1 may require a lower rebate to county 2 , forcing country 2 to raise taxes or cut transfer payments still further. ${ }^{23}$

\section{Empirical Aspects of Policy Interactions}

Given the differences in the equilibria described above, it might seem straightforward to distinguish an equilibrium time series generated by active monetary/passive fiscal policies from a time series generated by passive monetary/active fiscal policy. Unfortunately, subtle

\footnotetext{
${ }^{22}$ In this setting, where all goods are traded, the size of country 1 does not matter: Greece can determine euro-wide price levels. Incorporating non-traded goods and distinguishing among country-specific and eurowide price levels attenuates this stark and implausible result.

${ }^{23}$ Implicit in the equilibrium condition pertaining to the central bank's liabilities, (73), is the notion that if transfers to country 2 are unbounded above, then transfers (taxes) to country 1 must be unbounded below. This underscores that there may be limits to the ability of the central bank to retain control of inflation if one member of the union pursues an active fiscal policy.
} 
observational equivalence results may make it difficult to identify which regime is "active" and which regime is "passive." In this section we highlight two identification challenges - one in which observational equivalence exists between determinant and indeterminant equilibrium, which follows Cochrane (2011a), and another that demonstrates the challenges in distinguishing between regimes $\mathrm{M}$ and $\mathrm{F}$ from empirical observation. We view these results as provocative but only suggestive - further study is needed to determine whether the results generalize to more sophisticated setups. One implication flows even from the simple experiments conducted here: empirically testing for the interactions between monetary and fiscal policy by examining simple correlations in the data will lead to spurious results and potentially false conclusions. This suggests that existing efforts to "test" for the fiscal theory may be more challenging than originally believed [?, Canzoneri, Cumby, and Diba (2001), Cochrane (1998, 2005), Woodford (1998a, 2001), Leeper (1991), Sims (2011)].

4.1 Indeterminacy and Observational Equivalence There is a straightforward observational equivalence due to Cochrane (2010, 2011a) in which indeterminant equilibria can generate time series that are indistinguishable (same covariance generating process) from determinant ones.

To show this result, consider the simple model consisting of a Fisher relation and monetary policy rule

$$
\begin{gathered}
R_{t}=r+E_{t} \pi_{t+1} \\
R_{t}=r+\alpha \pi_{t}+x_{t} \\
x_{t}=b(L) \varepsilon_{x, t}
\end{gathered}
$$

where $R_{t}$ is the nominal interest rate, $\pi_{t}$ is inflation, and $r$ is the constant real rate. The only restriction we impose on the stochastic process for the monetary policy disturbance, $x_{t}$, is square summability, $\sum_{j} b_{j}^{2}<\infty$. The following proposition shows that there exists a stochastic process for the monetary policy rule that generates an observational equivalence between the determinant and indeterminant equilibria.

Proposition 1. (Cochrane) For any stationary time series process for $\left\{R_{t}, \pi_{t}\right\}$ that solves

$$
E_{t} \pi_{t+1}=\alpha \pi_{t}+x_{t}
$$

and for any $\alpha$, one can construct an $x_{t}$ process that generates the same process for the observables $\left\{R_{t}, \pi_{t}\right\}$ as a solution to (76) using the alternative $\alpha$. If $\alpha>1$, the observables are generated as the unique bounded forward-looking solution. Given an assumed $\alpha$ and the 
process $\pi_{t}=a(L) \varepsilon_{x, t}$, where $a(L)$ is a polynomial in the lag operator $L$, we can construct $x_{t}=b(L) \varepsilon_{x, t}$ with

$$
b_{j}=a_{j+1}-\alpha a_{j}
$$

or

$$
b(L)=\left(L^{-1}-\alpha\right) a(L)-a(0) L^{-1}
$$

Proof. To prove the proposition note that for $\alpha>1$ and $x_{t}=b(L) \varepsilon_{x, t}$, the unique $\pi_{t}$ is given by

$$
\pi_{t}=\left(\frac{L b(L)-\alpha^{-1} b\left(\alpha^{-1}\right)}{1-\alpha L}\right) \varepsilon_{x, t}=a(L) \varepsilon_{x, t}
$$

For $\alpha<1$, the equilibrium will not be uniquely determined and one may construct a $\pi_{t}$ solved "backward" to obtain, $\pi_{t}=x_{t} /(1-\alpha L)$. Specifying $b(L)$ as (77) and substituting into (78) gives $\pi_{t}=x_{t} /(1-\alpha L)$. Under this restriction, the inflation process generated by $\alpha<1$ will be identical to the inflation process generated by $\alpha>1$. Proving the converse (starting with $\alpha<1$ and showing that there exists an $\alpha>1$ that generates the observational equivalence) is straightforward since one can always write the solution as $\pi_{t+1}=\alpha \pi_{t}+x_{t}+\delta_{t+1}$, where $\delta_{t+1}$ is an arbitrary shock. In this case, setting $\delta_{t+1}=a_{0} \varepsilon_{t+1}$ delivers the result. Note that because $R_{t}=r+E_{t} \pi_{t+1}$, matching the inflation process also delivers an equivalence in the nominal interest rate.

The proposition illustrates that important identifying restrictions are imposed on the model through the specification of the exogenous processes. The cross-equation restrictions of (78) make clear the tight relationship between exogenous and endogenous variables. As Cochrane (2011a) emphasizes, for an exogenous process given by (77), it is impossible to tell if observed time series are generated by a determinant or an indeterminate equilibrium.

Proposition 1 relies on the indeterminant equilibria taking a very particular form. But by definition, there are an infinite number of indeterminant equilibria. We now show that a type of observational equivalence, similar in spirit to proposition 1, applies for unique equilibria that emerge from models with decoupled determinacy regions. The two regimes described in section 2, for example, arise from decoupled determinacy regions, as do many of the linear rational expectation models that researchers and policy institutions use to study monetary-fiscal interactions. Examining the dynamic properties of the two equilibria for general exogenous processes delivers an equivalence between the two unique rational expectations equilibria, which we believe is a more provocative finding than proposition 1.

This section establishes that observational equivalence results can emerge when examining fiscal and monetary interactions. Our example is a trivial one and we do not provide 
a rigorous treatment of the issues here; a careful treatment would require more than a few pages and is beyond the scope of the current paper. But even this simple demonstration is sufficient to signal a note of caution when examining the empirical aspects of monetary-fiscal interactions.

To the model in section 2, add monetary and fiscal policy rules that are deterministic and obey

$$
\begin{aligned}
& R_{t}=R^{*} \pi_{t}^{\alpha} \\
& s_{t}=s^{*} b_{t-1}^{\gamma}
\end{aligned}
$$

for $t \geq 0$, where $\pi_{t} \equiv P_{t} / P_{t-1}$ and $b_{t} \equiv B_{t} / P_{t}$. As in section 2 , we examine the two policy regimes (Regime $\mathrm{M}$ and Regime $\mathrm{F}$ ), defined in terms of the monetary and fiscal parameters, $(\alpha, \gamma)$.

The log-linearized equilibrium equations are given by

$$
\begin{aligned}
\hat{R}_{t} & =\hat{\pi}_{t+1} \\
\hat{b}_{t}+\left(\beta^{-1}-1\right) \hat{s}_{t} & =\beta^{-1} \hat{b}_{t-1}+\beta^{-1}\left(\hat{R}_{t-1}-\hat{\pi}_{t}\right)
\end{aligned}
$$

where $\hat{x}_{t} \equiv \ln \left(x_{t}\right)-\ln \left(x^{*}\right)$ and we have used that in steady state, $s / b=\beta^{-1}-1$. These equations hold for $t \geq 0$, given $R_{-1} b_{-1}>0$.

Substituting the linearized policy rules, (79) and (80), into (81) and (82) reduces the system to

$$
\begin{aligned}
\hat{\pi}_{t+1} & =\alpha \hat{\pi}_{t}, \quad t \geq 0 \\
\hat{b}_{t}+\beta^{-1} \hat{\pi}_{t} & =\gamma^{*} \hat{b}_{t-1}+\alpha \beta^{-1} \hat{\pi}_{t-1}, \quad t \geq 1 \\
\hat{b}_{0}+\left(\beta^{-1}-1\right) \hat{s}_{0} & =\beta^{-1}\left(\hat{b}_{-1}+\hat{R}_{-1}\right)
\end{aligned}
$$

where $\gamma^{*} \equiv \beta^{-1}-\gamma\left(\beta^{-1}-1\right)$.

For ease of exposition, we consider the special case in which $R_{-1} B_{-1}$ is at its steady state value, so $\hat{b}_{-1}=\hat{R}_{-1}=0 .{ }^{24}$

Consider Regime $\mathrm{M}$ in which $\alpha>1$ and $\gamma>1$ (implying that $0<\gamma^{*}<1$ ). There is a

\footnotetext{
${ }^{24}$ If instead $R_{-1} B_{-1}>0$, the results that follow continue to hold, but in modified form. Regime $\mathrm{M}$ and Regime $\mathrm{F}$ equilibria can still be observationally equivalent-delivering identical equilibrium paths for $\left\{\hat{R}_{t}, \hat{\pi}_{t}, \hat{b}_{t}, \hat{s}_{t}\right\}$ for $t \geq 0$ but under different fiscal rules from the ones considered here. Differences come from the fact that, although $\hat{R}_{t}=\hat{\pi}_{t}=0, t \geq 0$ continues to hold, the present value of surpluses must equal initial debt, $\hat{b}_{-1}+\hat{R}_{-1}$. Regime $\mathrm{M}$ implements this by setting $\gamma>1$, while Regime $\mathrm{F}$ implements this with an exogenous process for $\left\{\hat{s}_{t}\right\}$. Given time paths for equilibrium $\left\{\hat{R}_{t}, \hat{\pi}_{t}, \hat{s}_{t}\right\}$, the equilibrium debt sequence comes from (82).
} 
unique bounded equilibrium of a trivial form

$$
\hat{\pi}_{t}=0, \quad \hat{R}_{t}=0, \quad \hat{b}_{t}=0, \quad \hat{s}_{t}=0, \quad \text { for all } t \geq 0
$$

We can implement the equilibrium in (86) by adopting the passive monetary and active fiscal policy rules

$$
\begin{aligned}
\hat{R}_{t} & =0 \\
\hat{s}_{t} & =0
\end{aligned}
$$

for $t \geq 0$. These rules emerge when $\alpha=\gamma=0$.

These policy rules can deliver the remaining aspects of the Regime M equilibrium in (86). $\hat{R}_{t}=0, t \geq 0$ and a constant real interest rate imply that $\hat{\pi}_{t+j}=0$ for $j \geq 1$. $\hat{R}_{t}=0$ and $\hat{s}_{t}=0, t \geq 0$, imply that (because $\gamma=0, \gamma^{*}=\beta^{-1}$ ) in equilibrium the law of motion for debt is

$$
\hat{b}_{t}=\beta^{-1} \hat{b}_{t-1}-\beta^{-1} \hat{\pi}_{t}
$$

Iterating forward on this law of motion and taking expectations yields

$$
\hat{b}_{t}=\sum_{j=1}^{\infty} \beta^{j} \hat{\pi}_{t+j}=0
$$

But if $\hat{b}_{t}=0$, then (89) implies that $\hat{\pi}_{t}=0$, delivering precisely the equilibrium in (86). Constant primary surpluses and pegged nominal interest rates imply that future financing of debt is constant, which fixes the value of debt.

This derivation shows that when the equilibrium real interest rate is constant, the unique bounded equilibrium produced by Regime $\mathrm{M}$ can be exactly reproduced by Regime $\mathrm{F}$.

These results are merely suggestive of problems that lurk in the endeavor to identify whether observed time series are produced by Regime M or Regime F. One can easily construct monetary models in which determinacy regions are not decoupled (and ignoring fiscal policy altogether is not a viable way of achieving decoupling, in our view). For example, a Blanchard (1985)-Yaari (1965) model with a probability of death, can generate wealth effects that modify the determinacy regions sufficiently that it is no longer tenable to maintain the distinctions between monetary and fiscal policy [Richter (2011)]. Yun (2011) develops a number of mechanisms - learning, sovereign risk, financial frictions, and alternative roles for government debt - that break the decoupling by introducing debt directly into the consumption Euler equation. It is also not clear if these identification problems extend to more general setups. The more sophisticated the model and policy rule, the greater the likelihood 
that the identification problems discussed here become less severe.

Scant attention has been paid to these identification issues in the literature [but see Cochrane (2011a) and Sims (2011) for exceptions]. Many authors have attempted to discern whether equilibrium data were generated by Regime M or Regime F. Many of these attempts use reduced-form models in which policy behavior is not identified, relying instead on the restrictions imposed by the government's intertemporal financing constraint to identify policy regimes. These efforts cannot work: the government's budget constraint and the associated intertemporal equilibrium condition must be satisfied in any equilibrium, regardless of the underlying policy regimes.

\section{Concluding Remarks}

An argument that holds substantial currency among economists and policy makers is that central bankers learned the lessons of past periods of high inflation that, for example, Fischer, Sahay, and Végh (2002) document. First, too-rapid money growth generates inflation. Second, operationally separating the central bank from the fiscal authority ensures that the finance ministry cannot require the central bank to provide any specific cash flows or seigniorage revenues. The understanding of the connection between money growth and inflation, coupled with the operational independence of the central bank, the argument goes, permits the monetary authorities today to achieve their policy objectives.

This argument builds on Friedman's (1970) aphorism that "inflation is always and everywhere a monetary phenomenon" and it makes an implicit and essential assumption: fiscal policy will always behave in the "appropriate" manner. Sims (1999, p. 424) defines "appropriate" fiscal behavior in his description of central bank independence: "A truly independent central bank is one that can act, even under inflationary or deflationary stress, without any worry about whether the necessary fiscal backing for its actions will be forthcoming." That is, if in pursuit of its objectives a central bank were to encounter balance sheet difficulties, an independent bank would be automatically recapitalized by the fiscal authority.

Sims's point connects to Wallace's (1981) Modigliani-Miller theorem for open-market operations: the impacts of central bank asset swaps depend on fiscal policy behavior. In Wallace's paper, open-market sales of bonds have no effects on equilibrium allocations and prices. Under alternative assumptions on fiscal behavior, such monetary contractions may reduce inflation, while under Sargent and Wallace's (1981) assumptions, the contractions raise inflation.

The theory presented above introduces an additional dimension to the monetary-fiscal interactions that Wallace considers: the channel for price-level determination that operates through nominally denominated outstanding government debt and expected future primary 
fiscal surpluses. Because this channel is more subtle than Sargent and Wallace's monetization mechanism, fiscal policy can affect inflation even if an operationally independent central bank dutifully avoids printing new fiat money to cover fiscal budget shortfalls.

Policy makers need a broad understanding of the factors that determine inflation. The conventional view, what we call Regime M, proposes that monetary policy can control inflation. A requirement of this view is that fiscal policy must reliably adjust surpluses to ensure that government debt is stable. When governments issue nominal debt, an alternative mix of policies-Regime F-reverses the roles of the two macro policies, with fiscal policy determining inflation and monetary policy stabilizing debt.

If current and projected fiscal stress in advanced economies continues unresolved, economic agents will grow more uncertain that the fiscal adjustments that Regime $\mathrm{M}$ requires will occur. And central bank behavior in recent years has shown people that monetary policy does not always aggressively lean against inflation - at times, other concerns are paramount. As beliefs become increasingly centered on Regime F, monetary policy loses its ability to control inflation and influence economic activity in the usual ways. Because these developments are driven primarily by fiscal behavior, there is little that independent central bankers can do to anchor expectations on Regime M policies.

Regimes $\mathrm{M}$ and $\mathrm{F}$ produce equilibria in which monetary and fiscal disturbances have very different effects on macroeconomic time series. Despite these differences, we have shown that it can be difficult to determine which regime generated observed data.

This conclusion may seem iconoclastic or even depressing. But if observational equivalence extends to more general classes of models, such as those that policy institutions employ, then it points toward two constructive conclusions for policy modeling. First, policy modelers could adopt more general driving processes and be aware that they achieve identification through arbitrary assumptions about unobservables. Second, to the extent that simple ad hoc specifications of policy rules are integral to interpretations of data, these specifications can be varied to admit more general interpretations.

There is also a message in these results for policy makers themselves. Because two very different understandings of the inflation process can be equally consistent with observed data, it is prudent to broaden the perspective on inflation determination beyond the single, conventional view that dominates policy thinking. 


\section{REFERENCES}

Bassetto, M. (2002): "A Game-Theoretic View of the Fiscal Theory of the Price Level," Econometrica, 70(6), 2167-2195.

Bergin, P. R. (2000): "Fiscal Solvency and Price Level Determination in a Monetary Union," Journal of Monetary Economics, 45(1), 37-53.

BI, H. (2011): "Sovereign Risk Premia, Fiscal Limits and Fiscal Policy," forthcoming, European Economic Review.

Bi, H., E. M. Leeper, And C. Leith (2010): "Stabilization versus Sustainability: Macroeconomic Policy Tradeoffs," Manuscript, Indiana University, November.

Blanchard, O. J. (1985): "Debts, Deficits, and Finite Horizons," Journal of Political Economy, 93(2), 223-247.

Bordo, M. D., And P.-C. Hautcoeur (2007): "Why Didn't France Follow the British Stabilisation After World War I?," European Review of Economic History, 11(1), 3-37.

Buiter, W. H. (2002): "The Fiscal Theory of the Price Level: A Critique," Economic Journal, 112(481), 459-480.

Canzoneri, M. B., R. E. Cumby, and B. T. Diba (2001): "Is the Price Level Determined by the Needs of Fiscal Solvency?," American Economic Review, 91(5), 1221-1238.

Cecchetti, S. G., M. S. Mohanty, and F. Zampolli (2010): "The Future of Public Debt: Prospects and Implications," BIS Working Papers No. 300, Monetary and Economic Department, March.

Cochrane, J. H. (1998): "A Frictionless View of U.S. Inflation," in NBER Macroeconomics Annual 1998, ed. by B. S. Bernanke, and J. J. Rotemberg, vol. 14, pp. 323-384. MIT Press, Cambridge, MA.

(2001): "Long Term Debt and Optimal Policy in the Fiscal Theory of the Price Level," Econometrica, 69(1), 69-116.

— (2005): "Money as Stock," Journal of Monetary Economics, 52(3), 501-528.

— (2009): "Understanding Fiscal and Monetary Policy in 2008-2009," Manuscript, University of Chicago. 
(2010): "Online Appendix to 'Determinacy and Identification with Taylor Rules'," Manuscript, University of Chicago, September.

(2011a): "Determinacy and Identification with Taylor Rules," Journal of Political Economy, 119(3), 565-615.

- (2011b): "Inflation and Debt," National Affairs, Fall(9), 56-78.

(2011c): "Understanding Policy in the Great Recession: Some Unpleasant Fiscal Arithmetic," European Economic Review, 55(1), 2-30.

DAniel, B. C. (2001): "The Fiscal Theory of the Price Level in an Open Economy," Journal of Monetary Economics, 48(2), 293-308.

Daniel, B. C., And C. Shiamptanis (2011): "Fiscal Risk in a Monetary Union," Manuscript, University at Albany-SUNY, January.

DAvig, T., And E. M. Leeper (2006): "Fluctuating Macro Policies and the Fiscal Theory," in NBER Macroeconomics Annual 2006, ed. by D. Acemoglu, K. Rogoff, and M. Woodford, vol. 21, pp. 247-298. MIT Press, Cambridge.

- (2011): "Monetary-Fiscal Policy Interactions and Fiscal Stimulus," European Economic Review, 55(2), 211-227.

Davig, T., E. M. Leeper, and T. B. Walker (2010): “Unfunded Liabilities' and Uncertain Fiscal Financing," Journal of Monetary Economics, 57(5), 600-619.

(2011): "Inflation and the Fiscal Limit," European Economic Review, 55(1), 31-47.

Dixit, A., And L. Lambertini (2001): "Monetary-Fiscal Policy Interactions and Commitment versus Discretion in a Monetary Union," European Economic Review, 45(4-6), $977-987$.

- (2003a): "Interactions of Commitment and Discretion in Monetary and Fiscal Policies," American Economic Review, 93(5), 1522-1542.

(2003b): "Symbiosis of Monetary and Fiscal Policies in a Monetary Union," Journal of International Economics, 60(2), 235-247.

Dupor, B. (2000): "Exchange Rates and the Fiscal Theory of the Price Level," Journal of Monetary Economics, 45(3), 613-630. 
Eusepi, S., And B. Preston (2011): "Learning the Fiscal Theory of the Price Level: Some Consequences of Debt-Management Policy," forthcoming in Journal of the Japanese and International Economies.

Fischer, S., R. SAhay, And C. A. VÉGH (2002): "Modern Hyper- and High Inflations," Journal of Economic Literature, 40(3), 837-880.

Friedman, M. (1970): The Counter-Revolution in Monetary Theory. Institute of Economic Affairs, London.

Galí, J. (2008): Monetary Policy, Inflation, and the Business Cycle. Princeton University Press, Princeton.

Gambacorta, L. (2008): "How Do Banks Set Interest Rates?," European Economic Review, 52, 792-819.

Gordon, D. B., And E. M. Leeper (2006): "The Price Level, The Quantity Theory of Money, and the Fiscal Theory of the Price Level," Scottish Journal of Political Economy, $53(1), 4-27$.

Hall, G. J., and T. J. Sargent (2011): "Interest Rate Risk and Other Determinants of Post-WWII U.S. Government Debt/GDP Dynamics," American Economic Journal: Macroeconomics, 3(3), 1-27.

International Monetary Fund (2009): "Fiscal Implications of the Global Economic and Financial Crisis," IMF Staff Position Note SPN/09/13.

— (2011): World Economic Outlook. IMF, Washington, D.C., April.

KIm, S. (2003): "Structural Shocks and the Fiscal Theory of the Price Level in the Sticky Price Model," Macroeconomic Dynamics, 7(5), 759-782.

KInG, M. (1995): "Commentary: Monetary Policy Implications of Greater Fiscal Discipline," in Budget Deficits and Debt: Issues and Options, pp. 171-183. Federal Reserve Bank of Kansas City, Jackson Hole Symposium.

King, R. G., And C. I. Plosser (1985): "Money, Deficits, and Inflation," CarnegieRochester Conference Series on Public Policy, 22, 147-196.

Leeper, E. M. (1991): "Equilibria Under 'Active' and 'Passive' Monetary and Fiscal Policies," Journal of Monetary Economics, 27(1), 129-147. 
(2011): "Anchors Aweigh: How Fiscal Policy Can Undermine "Good" Monetary Policy," in Monetary Policy Under Financial Turbulence, ed. by L. F. Céspedes, R. Chang, and D. Saravia, pp. 411-453. Banco Central de Chile, Santiago.

Leeper, E. M., And T. B. Walker (2011): "Fiscal Limits in Advanced Economies," Economic Papers: A Journal of Applied Economics and Policy, 30(1), 33-47.

LI, B. (2011): "On the Identification of Fiscal Policy Behavior," Manuscript, Tsinghua University, May.

Loyo, E. (1999): "Tight Money Paradox on the Loose: A Fiscalist Hyperinflation," Manuscript, Harvard University.

McCallum, B. T. (2001): "Indeterminacy, Bubbles, and the Fiscal Theory of Price Level Determination," Journal of Monetary Economics, 47(1), 19-30.

Obstfeld, M., and K. Rogoff (1983): "Speculative Hyperinflations in Maximizing Models: Can We Rule Them Out?," Journal of Political Economy, 91(4), 675-687.

Richter, A. W. (2011): "The Fiscal Limit and Non-Ricardian Consumers," Manuscript, Indiana University, November.

Sargent, T. J., And N. Wallace (1981): "Some Unpleasant Monetarist Arithmetic," Federal Reserve Bank of Minneapolis Quarterly Review, 5(Fall), 1-17.

Schabert, A. (2010): "Monetary Policy Under a Fiscal Theory of Sovereign Default," Journal of Economic Theory, 145(2), 860-868.

Sims, C. A. (1994): "A Simple Model for Study of the Determination of the Price Level and the Interaction of Monetary and Fiscal Policy," Economic Theory, 4(3), 381-399.

- (1997): "Fiscal Foundations of Price Stability in Open Economies," Manuscript, Yale University.

- (1999): "The Precarious Fiscal Foundations of EMU," De Economist, 147(4), 415436.

(2008): "Government and Central Bank Balance Sheets, Inflation and Monetary Policy," Slides, Princeton University, November 3.

- (2011): "Stepping on a Rake: The Role of Fiscal Policy in the Inflation of the 1970's," European Economic Review, 55(1), 48-56. 
Trabandt, M., and H. Uhlig (2010): "How Far Are We From the Slippery Slope? The Laffer Curve Revisited," forthcoming, Journal of Monetary Economics.

URIBE, M. (2006): "A Fiscal Theory of Sovereign Risk," Journal of Monetary Economics, $53(8), 1857-1875$.

Wallace, N. (1981): "A Modigliani-Miller Theorem for Open-Market Operations," American Economic Review, 71(3), 267-274.

Woodford, M. (1995): "Price-Level Determinacy Without Control of a Monetary Aggregate," Carnegie-Rochester Conference Series on Public Policy, 43, 1-46.

(1998a): "Comment on Cochrane's 'A Frictionless View of U.S. Inflation'," in NBER Macroeconomics Annual 1998, ed. by B. S. Bernanke, and J. J. Rotemberg, pp. 390-419. MIT Press, Cambridge, MA.

- (1998b): "Control of the Public Debt: A Requirement for Price Stability?," in The Debt Burden and Its Consequences for Monetary Policy, ed. by G. Calvo, and M. King, pp. 117-154. St. Martin's Press, New York.

- (2001): "Fiscal Requirements for Price Stability," Journal of Money, Credit, and Banking, 33(3), 669-728.

(2003): Interest and Prices: Foundations of a Theory of Monetary Policy. Princeton University Press, Princeton, N.J.

YAARI, M. E. (1965): "Uncertain Lifetime, Life Insurance, and the Theory of the Consumer," The Review of Economic Studies, 32(2), 137-150.

Yun, T. (2011): "Transmission Mechanisms of the Public Debt," Manuscript, Seoul National University, October. 